\title{
Acute and Chronic Effects of Cocaine on Cardiovascular Health
}

\author{
Sung Tae Kim ${ }^{1}$ (D) and Taehwan Park $2,3, *$ (D) \\ 1 Department of Pharmaceutical Engineering, Inje University, Gimhae 50834, Korea; stkim@inje.ac.kr \\ 2 Pharmacy Administration, St. Louis College of Pharmacy, St. Louis, MO 63110, USA \\ 3 Center for Health Outcomes Research and Education, St. Louis College of Pharmacy, \\ St. Louis, MO 63110, USA \\ * Correspondence: Taehwan.Park@stlcop.edu; Tel.: +1-314-446-8193
}

Received: 8 January 2019; Accepted: 27 January 2019; Published: 29 January 2019

\begin{abstract}
Cardiac complications resulting from cocaine use have been extensively studied because of the complicated pathophysiological mechanisms. This study aims to review the underlying cellular and molecular mechanisms of acute and chronic effects of cocaine on the cardiovascular system with a specific focus on human studies. Studies have consistently reported the acute effects of cocaine on the heart (e.g., electrocardiographic abnormalities, acute hypertension, arrhythmia, and acute myocardial infarction) through multifactorial mechanisms. However, variable results have been reported for the chronic effects of cocaine. Some studies found no association of cocaine use with coronary artery disease (CAD), while others reported its association with subclinical coronary atherosclerosis. These inconsistent findings might be due to the heterogeneity of study subjects with regard to cardiac risk. After cocaine use, populations at high risk for CAD experienced coronary atherosclerosis whereas those at low risk did not experience CAD, suggesting that the chronic effects of cocaine were more likely to be prominent among individuals with higher CAD risk. Studies also suggested that risky behaviors and cardiovascular risks may affect the association between cocaine use and mortality. Our study findings highlight the need for education regarding the deleterious effects of cocaine, and access to interventions for cocaine abusers.
\end{abstract}

Keywords: cocaine; cardiovascular health; heart disease; acute effects; chronic effects

\section{Introduction}

Cocaine is a tropane alkaloid compound that can be extracted from the leaves of an Andean shrub, Erythroxylon coca, in South America. Cocaine was originally used for local surgeries as an anesthetic agent in the 1880s, but it became a recreational drug in the 1970s. In the 1980s, there was an epidemic of cocaine use, with the number of cocaine users in the US estimated at 5.8 million in 1985 [1]. In 2016, the total number of cocaine users was estimated to be 18.2 million worldwide [2]. Approximately $34 \%$ of these cocaine users resided in North America, and 20\% resided in Western and Central Europe. In the US, there were 1.5 million cocaine users aged 12 or older, representing $0.6 \%$ of the population [3]. Young adults aged 18 to 25 were the most common cocaine users (1.4\%).

Cocaine may be administered by smoking, intravenous injection, nasal inhalation, or oral application. Pharmacokinetics vary by route of administration, with time to peak blood concentration ranging from 1-5 min (smoking or intravenous injection) to 60-90 min (oral administration) [4,5]. The duration of pharmacological action ranges between 5-60 min following smoking or intravenous administration, and up to $180 \mathrm{~min}$ following oral administration. In addition to nasal mucous membranes, cocaine absorption through other mucous membranes such as intravaginal or intrarectal mucus membranes is also possible [6]. Cocaine administration through mucous membranes results in 
slower onset of action, later peak concentration, and longer duration of action compared with that of smoking or intravenous administration, but faster onset of action, earlier peak concentration, and shorter duration of action than that of oral administration. Cocaine is converted into two major metabolites by plasma and liver cholinesterases: benzoylecgonine and ecgonine methyl ester. These water-soluble metabolites are excreted in the urine and are detectable in the urine for 24 to $36 \mathrm{~h}$ after intake.

Cocaine is categorized as a Schedule II substance under the Controlled Substances Act. Drugs or substances in this schedule have a high potential for abuse, which may lead to severe psychological or physical dependence. Cocaine abuse can result in a range of adverse health outcomes. About 0.9 million U.S. adults had a cocaine use disorder in 2014 [7]. Approximately $40 \%$ of all emergency department visits related to drug misuse and abuse were attributed to cocaine [8].

Prior studies have consistently reported the deleterious effects of cocaine use/abuse on the cardiovascular system. Cocaine-related cardiac complications include acute conditions such as arrhythmia and acute myocardial infarction (MI), as well as chronic conditions such as cardiomyopathy and coronary artery disease (CAD). Cocaine-induced cardiotoxicity can result in sudden death. In addition, previous studies have explored the complicated pathophysiological mechanisms of cocaine cardiotoxicity. Herein, we first review the cellular and molecular mechanisms of cocaine in the cardiovascular system to obtain a better understanding of its acute and chronic effects on the heart and blood vessels. Furthermore, we discuss recent evidence from human studies that examined cocaine-associated changes in the cardiovascular system. As such, our review includes recent clinical studies that have been published in the past 10 years (from September 2008 through September 2018) retrieved from the Medline database, and several other important clinical studies published before September 2008.

\section{Pathophysiological Mechanisms of Cocaine on Cardiovascular Health}

Cocaine stimulates the sympathetic nervous system by inhibiting reuptake of norepinephrine, dopamine, and serotonin by interacting with each transporter, leading to exaggerated, prolonged sympathetic nervous system activity $[9,10]$. Cocaine also blocks sodium/potassium channels, which induces abnormal, depressed cardiovascular profiles [11]. In particular, concurrent cocaine and alcohol abuse significantly increases cocaine levels in the blood, leading to increased, prolonged cardiovascular risks [12]. Previous studies have reported that use/abuse of cocaine is associated with increased risk of subsequent cardiovascular complications such as hypertension, coronary spasm, arrhythmias, MI, cardiomyopathy, atherosclerosis, and CAD [13], as summarized in Figure 1. In this section, we summarize the acute and chronic pathophysiological mechanisms of cocaine on cardiovascular health.

\subsection{Mechanisms of Acute Toxicity}

\subsubsection{Acute Hypertension and Coronary Spasm}

Acute coronary events usually occur within minutes to hours after cocaine administration. Cocaine stimulates the adrenergic system by binding to norepinephrine transporters, resulting in increased norepinephrine effects at postsynaptic receptor sites. Blocking norepinephrine reuptake induces tachycardia and hypertension, which increases myocardial oxygen demand and reduces myocardial oxygen supply by vasoconstriction $[11,14,15]$. As such, cocaine induces sympathetic effects on the cardiovascular system by enhanced inotropic and chronotropic effects through increased vasoconstriction. In particular, cocaine induces acute hypertension due to increased vasoconstriction induced by increased endothelin-1 [16], impaired acetylcholine-induced vasorelaxation [17], inhibition of nitric oxide synthase [18], impaired intracellular calcium handling [19], and inhibition of sodium/potassium channels [20] as determined by cellular and molecular analytical approaches [11]. In addition, acute vessel damage induces platelet aggregation/blood clots through increased fibrinogen 
and von Willebrand factor, leading to acute heart damage due to reduced blood flow [21]. Taken together, cocaine induces acute hypertension, coronary spasm, which may lead to subsequent myocardial infarction.

\begin{tabular}{|c|c|}
\hline Effects of cocaine on the heart & Effects of cocaine on blood vessels \\
\hline $\begin{array}{l}\text { Arrhythmias } \\
\text { Inhibition of sodium channels: Increased heart } \\
\text { rate and acidity } \\
\text { Inhibition of potassium channels: Prolongation of } \\
\text { QT interval, early afterdepolarization, and } \\
\text { ventricular tachyarrhythmia } \\
\text { Acute myocardial infarction (MI) } \\
\text { (Low dose) } \\
\text { Increased heart rate, blood pressure, and } \\
\text { myocardial contractibility } \\
\text { Coronary spasm/vasoconstriction and } \\
\text { platelet adherence/thrombosis } \\
\text { Increased myocardial oxygen demand and } \\
\text { decreased myocardial oxygen supply: Imbalanc } \\
\text { e between oxygen supply and demand } \\
\text { (High dose) } \\
\text { Blockage of sodium transport and norepinephrine } \\
\text { uptake in the myocardium: Decreased left } \\
\text { ventricular contractibility and prolongation of } \\
\text { QRS and QT intervals } \\
\text { Vessel damages/ruptures and thrombosis } \\
\text { Cardiomyopathy } \\
\text { - Non-ischemic myocardial depression: Dilated }\end{array}$ & $\begin{array}{l}\text { Acute hypertension and coronary spasm } \\
\text { Inhibition of norepinephrine reuptake } \\
\text { Increased vasoconstriction } \\
\text { by increased endothelin-1, impaired } \\
\text { vasorelaxation, inhibited NO synthase, impaire } \\
\text { d intracellular calcium handling, and inhibited } \\
\text { sodium/potassium channels } \\
\text { Platelet aggregation/blood clots } \\
\text { Atherosclerosis } \\
\text { Impaired NO release } \\
\text { Increased levels of cell adhesion molecules, low-d } \\
\text { ensity lipoprotein migration, leukocyte } \\
\text { migration, and intimal smooth muscle cells } \\
\text { within the coronary artery wall } \\
\text { Coronary artery disease } \\
\text { - Vasoconstriction of coronary artery and } \\
\text { vasospasm by stimulating adrenergic receptor } \\
\text { - Promoted intracoronary thrombosis } \\
\text { - Accelerated atherosclerosis }\end{array}$ \\
\hline $\begin{array}{l}\text { - Left ventricular hypertrophy } \\
\text { - Catecholamine toxicity: Myocarditis }\end{array}$ & $\begin{array}{l}\text { Cocaine }\left(\mathrm{C}_{17} \mathrm{H}_{21} \mathrm{NO}_{4}\right) \\
\text { - Tropane alkaloid compound from Erythroxylon coca } \\
\text { - } 18.2 \text { million cocaine users in } 2016 \\
\text { - Administration through smoking, intravenous injection, inhalation, or oral application } \\
\text { - Deleterious effects on the cardiovascular system }\end{array}$ \\
\hline
\end{tabular}

Figure 1. Effects of cocaine on cardiovascular health. Use of cocaine (bottom) results in both acute (italic) and chronic (normal) changes in the heart (left) and blood vessels (right). (Note: Cocaine often induces cardiac condition(s) (e.g., acute myocardial infarction (MI) and coronary artery disease) by affecting the heart and vessels simultaneously).

\subsubsection{Arrhythmias}

Previous studies have shown that cocaine inhibits cardiac ion channels such as sodium channels and potassium channels [22]. The upstroke of action potential was shown to be delayed in response to sodium channel blockade, which is modulated by heart rate and acidity. Increased heart rate and acidity boost the effect of cocaine on sodium channels [23,24]. Inhibition of sodium channels is intensified when cocaine is abused or when cocaethylene is formed after administration of cocaine with alcohol $[25,26]$. Cocaine effects on potassium channel blockade result in prolonged QT interval, early afterdepolarization, and ventricular tachyarrhythmia $[27,28]$. Similar to effects on sodium channels, cocaine abuse or cocaine use with alcohol exacerbates inhibition of potassium channels and QT prolongation [29]. In addition, cocaine administration increases body temperature, resulting in hyperthermia. Cocaine overdose can induce cardiac arrhythmias and result in an impaired electrocardiographic profile, which may be related to the increased prevalence of cocaine-associated mortality in hot weather and in crowded circumstances [30,31]. In addition to these factors, cardiac arrhythmias may be affected by other factors such as catecholamine excess and calcium channel blockade. Acidosis and electrolyte abnormalities can also modulate cardiac arrhythmias. [23]. As such, cocaine-induced cardiac arrhythmias can be generated via many mechanisms in cocaine users.

\subsubsection{Acute Myocardial Infarction}

Mechanisms of acute MI resulting from cocaine use are multifactorial. Cocaine and its metabolites are sympathomimetic agents [32] and induce local anesthetic effects [11]. At low doses, cocaine-induced 
sympathetic effects increase heart rate, blood pressure, and myocardial contractibility, leading to increased myocardial oxygen demand [33]. Cocaine also enhances coronary spasm/vasoconstriction and platelet adherence/thrombosis, leading to reduced myocardial oxygen supply [34]. Thus, an imbalance between oxygen supply and demand results in MI [35]. At high doses, cocaine-induced local anesthesia results in decreased left ventricular (LV) contractibility and prolongation of QRS and QT intervals in electrocardiograms by blocking sodium transport and norepinephrine uptake in the myocardium [4]. In vessels, cocaine contributes to MI by increasing endothelin-1 [36] and reducing nitric oxide production in endothelial cells [37]. When vessels are stressed, acute damages/ruptures can occur, which promotes thrombosis by increasing platelet activity/aggregation [38,39] and elevating fibrinogen levels [40] and plasminogen activator inhibitor activity [41,42]. These cellular and molecular cascades result in reduced cardiac blood flow, leading to acute MI and possibly atherosclerosis and coronary thrombosis in the long term [43,44]. As such, cocaine induces acute MI by directly affecting myocardial tissues in the heart and indirectly enhancing thrombosis in vessels.

\subsection{Mechanisms of Chronic Toxicity}

\subsubsection{Cardiomyopathy}

Cocaine causes systolic dysfunction or LV failure, which results from reduced ejection fraction and an enlarged left ventricular chamber [45]. Cocaine administration reduces myocardial contractility and ejection fraction [46] and enhances left ventricular end-diastolic pressure and end-systolic volume [47-49]. It may cause non-ischemic myocardial depression, leading to dilated cardiomyopathies such as Takotsubo cardiomyopathy, a type of non-ischemic cardiomyopathy [50]. Previous studies reported that cocaine-induced cardiomyopathy, especially dilated cardiomyopathy [51,52], resulting from deprivation of myocardial oxygen supply despite increased demand for oxygen, leads to reduced coronary blood flow. Dilated cardiomyopathy is the most common consequence of long-term cocaine use and can lead to several complications including heart failure and heart-valve defects [53]. Chronic abuse of cocaine is associated with left ventricular hypertrophy [54]. In addition, catecholamine toxicity from chronic cocaine use was shown to be associated with myocarditis [55], which was related to increased local immune reactions and myocardial necrosis [56].

\subsubsection{Atherosclerosis}

Coronary atherosclerosis often occurs in young cocaine users $[24,57]$ or cocaine users with other cardiovascular diseases (e.g., MI) [58]. According to previous studies, cocaine impairs nitric oxide release from endothelial cells [59,60]. In addition, cocaine increases levels of cell adhesion molecules (e.g., intracellular adhesion molecule-1 (ICAM-1), cluster of differentiation 54 (CD54), vascular cell adhesion molecule-1 (VCAM-1), endothelial leukocyte adhesion molecule-1 (ELAM-1)), low-density lipoprotein migration, and leukocyte migration in blood vessels [61]. Moreover, intimal smooth muscle cells within the coronary artery wall increase [24,62], presumably leading to progression of atherosclerosis and potential sudden cardiac death [63]. Based on immunological studies, mast cells in plaques may contribute to atherosclerosis, vasospasm, thrombosis, and sudden death [57,59,64]. Briefly, proteolytic substances released from mast cells accelerate atherosclerosis by degrading and facilitating uptake of low-density lipoprotein cholesterol by macrophages $[65,66]$. Histamine released from mast cells increases endothelial permeability, which leads to leukocyte migration [67]. As such, cocaine has complex effects on endothelial cell dysfunction, facilitates low-density lipoprotein and leukocyte migration, and increases intimal smooth muscle cells, all of which contribute to atherosclerosis in long-term users. 


\subsubsection{Coronary Artery Diseases}

Chronic cocaine use causes repetitive damages to the heart and vessels by interacting with norepinephrine transporters [68]. Alpha-2 adrenergic receptors induce vasoconstriction of coronary arteries through contraction of vascular smooth muscle cells [34], leading to prothrombotic effects caused by increased von Willebrand factor [21]. Cocaine induces vasospasm through stimulation of adrenergic receptors on coronary arteries [69]. Cocaine also promotes intracoronary thrombosis $[70,71]$ through increased von Willebrand factor release, increased levels of endothelial tissue factor, an important factor in pathogenesis of acute coronary syndrome (ACS), decreased levels of tissue factor pathway inhibitor [72], and accelerated atherosclerosis due to endothelial cell dysfunction [60]. In addition, long-term use of cocaine induces endothelial injury, vascular fibrosis [73,74], and subsequent vessel wall weakening [75], resulting in apoptosis of vascular smooth muscle cells and cystic medial necrosis [76,77]. According to previous reports, cocaine sometimes induces coronary and carotid aortic dissections [78-80]. Thus, cocaine causes coronary artery diseases through multifactorial mechanisms including vasoconstriction, intracoronary thrombosis, and accelerated atherosclerosis.

\section{Cocaine Cardiotoxicity in Human Studies}

Cocaine-induced cardiotoxicity can result in deleterious effects on the heart and vessels through multifactorial pathophysiological mechanisms, as described above. In this section, we focus on recent human studies published in the past 10 years, retrieved from the Medline database. Table 1 presents these studies that examined the association of cocaine use with both acute and chronic cardiovascular diseases and mortality.

\subsection{Acute Effects of Cocaine}

A number of studies have reported a possible link between cocaine use and acute cardiovascular conditions such as acute hypertension, arrhythmia, coronary artery aneurysms (CAAs), and acute MI. Because the study populations and data sources varied across the studies, the findings of these studies should be interpreted carefully in the context of each individual study.

Kozor et al. [81] in Australia compared blood pressure, aortic stiffness, and LV mass in cocaine users with those in cocaine non-users. The authors recruited 20 regular cocaine users aged $37 \pm 7$ years ( $85 \%$ male) and 20 control subjects aged $33 \pm 7$ years ( $95 \%$ male). This study defined regular cocaine use as using cocaine at least monthly during the year prior to when the study was conducted. The study findings showed that cocaine users had higher systolic blood pressure (134 \pm 11 vs. $126 \pm$ $11 \mathrm{~mm} \mathrm{Hg})$, increased aortic stiffness, and greater LV mass (124 \pm 25 vs. $105 \pm 16 \mathrm{~g})$ compared with cocaine non-users. 
Table 1. Acute and chronic effects of cocaine on the cardiovascular system.

\begin{tabular}{|c|c|c|c|c|c|c|c|}
\hline Study (year) & Country & Study Design & Data Source & $\begin{array}{l}\text { Study Population } \\
\text { (Sample Size) }\end{array}$ & $\begin{array}{l}\text { Male \%, Age } \\
(\text { mean } \pm \text { SD) }\end{array}$ & Outcome(s) & Findings \\
\hline \multicolumn{8}{|c|}{ Acute effects of cocaine } \\
\hline $\begin{array}{l}\text { Kozor et al. } \\
\text { (2014) [81] }\end{array}$ & Australia & Cross-sectional & Study participants & $\begin{array}{l}\text { Adults with no coronary } \\
\text { disease, no previous MI, } \\
\text { no contraindication to CMR } \\
\text { imaging, and no cocaine use } \\
\text { in the } 48 \text { h prior to image } \\
\text { acquisition ( } n=20 \text { for social } \\
\text { cocaine users; } n=20 \text { for } \\
\text { cocaine non-users) }\end{array}$ & $\begin{array}{c}85 \%, 37 \pm 7 \text { yrs in the } \\
\text { social cocaine users' } \\
\text { group; } 95 \%, 33 \pm 7 \text { yrs in } \\
\text { the cocaine } \\
\text { nonusers group }\end{array}$ & $\begin{array}{l}\text { Systolic blood pressure, } \\
\text { aortic stiffness, } \\
\text { and LV mass }\end{array}$ & $\begin{array}{l}\text { Cocaine use associated with high } \\
\text { systolic blood pressure ( } 134 \pm 11 \text { vs. } \\
126 \pm 11 \mathrm{mmHg} \text { ), increased aortic } \\
\text { stiffness, and greater } \mathrm{LV} \text { mass } \\
(124 \pm 25 \mathrm{vs} .105 \pm 16 \mathrm{~g}) \text { compared } \\
\text { with no cocaine use }\end{array}$ \\
\hline $\begin{array}{l}\text { Sharma et al. } \\
(2016)[43]\end{array}$ & US & Retrospective & $\begin{array}{l}\text { ECG recordings in the } \\
\text { Atherosclerosis Risk in } \\
\text { Communities (ARIC) } \\
\text { study from Aug. 2006 to } \\
\text { Dec. } 2014\end{array}$ & $\begin{array}{l}\text { Cocaine-dependent subjects } \\
(n=97) ; \text { non-cocaine-using } \\
\text { control subjects }(n=8513)\end{array}$ & $\begin{array}{l}86 \%, 50 \pm 4 \text { yrs in the } \\
\text { cocaine-dependent } \\
\text { subjects' group; } 46 \% \\
52 \pm 5 \text { yrs in the } \\
\text { controls group }\end{array}$ & Resting ECG parameters & $\begin{array}{c}\text { Significant effects of cocaine use on } \\
\text { early repolarization (OR }=4.92, \\
95 \% \text { CI: } 2.73-8.87), \text { bradycardia } \\
\text { (OR }=3.02,95 \% \text { CI: } 1.95-4.66) \text {, severe } \\
\text { bradycardia (OR }=5.11,95 \% \text { CI: } \\
2.95-8.84) \text {, and heart rate } \\
\text { (B weight }=-5.84,95 \% \text { CI: }-7.85 \\
\text { to }-3.82 \text { ) }\end{array}$ \\
\hline $\begin{array}{l}\text { Kariyanna et al. } \\
\quad(2018)[82]\end{array}$ & US & Case-report & Patient & $\begin{array}{l}\text { A } 55 \text {-year-old woman } \\
\text { presenting with a chest pain } \\
\text { after cocaine use }(n=1)\end{array}$ & $0 \%, 55$ yrs & $\begin{array}{c}\text { Second degree Mobitz } \\
\text { type II } \\
\text { atrioventricular block }\end{array}$ & $\begin{array}{l}\text { Cocaine-induced Mobitz type II } \\
\text { second degree atrioventricular block }\end{array}$ \\
\hline $\begin{array}{l}\text { Satran et al. } \\
(2005) \text { [83] }\end{array}$ & US & Retrospective & $\begin{array}{l}\text { Angiographic database at } \\
\text { Hennepin County } \\
\text { Medical Center } \\
\text { in Minnesota }\end{array}$ & $\begin{array}{c}\text { Patients with a history of } \\
\text { cocaine use }(n=112) ; \text { Patients } \\
\text { with no history of cocaine use } \\
(n=79)\end{array}$ & $\begin{array}{l}79 \%, 44 \pm 8 \text { yrs in the } \\
\text { cocaine users' group; } 61 \%, \\
46 \pm 5 \text { yrs in the cocaine } \\
\text { non-users group }\end{array}$ & CAA & $\begin{array}{l}\text { Significantly higher CAA in cocaine } \\
\text { users compared with cocaine } \\
\text { nonusers (30.4\% vs. } 7.6 \%)\end{array}$ \\
\hline $\begin{array}{l}\text { Gupta et al. } \\
(2014)^{1}[84]\end{array}$ & US & Retrospective & $\begin{array}{c}\text { Acute Coronary } \\
\text { Treatment and } \\
\text { Intervention Outcomes } \\
\text { Network Registry-Get } \\
\text { With The Guidelines } \\
\text { (ACTION } \\
\text { Registry-GWTG) }\end{array}$ & $\begin{array}{l}\text { Patients admitted within } 24 \mathrm{~h} \\
\text { of acute MI from July } 2008 \text { to } \\
\text { March } 2010(n=924 \text { in the } \\
\text { cocaine group; } n=102,028 \text { in } \\
\text { the non-cocaine group) }\end{array}$ & $\begin{array}{l}80 \%, 50 \text { (range: } 44-56 \text { ) yrs } \\
\text { in the cocaine group; } 65 \% \text {, } \\
64 \text { (range: } 54-76 \text { ) yrs in } \\
\text { the non-cocaine group }\end{array}$ & $\begin{array}{l}\text { Acute STEMI, cardiogenic } \\
\text { shock, multivessel CAD, } \\
\text { and in-hospital mortality }\end{array}$ & $\begin{array}{l}\text { Higher percentages of STEMI } \\
(46.3 \% \text { vs. } 39.7 \%) \text { and cardiogenic } \\
\text { shock (13\% vs. } 4.4 \%) \text { in the cocaine } \\
\text { group, but a lower percentage of } \\
\text { multivessel coronary artery disease } \\
(53.3 \% \text { vs. } 64.5 \%) \text {. Similar in-hospital } \\
\text { mortality between the cocaine group } \\
\text { and the non-cocaine group } \\
\text { (OR }=1.00,95 \% \text { CI: } 0.69-1.44)\end{array}$ \\
\hline $\begin{array}{l}\text { Salihu et al. } \\
\text { (2018) [85] }\end{array}$ & US & Retrospective & $\begin{array}{l}\text { National Inpatient Sample } \\
\text { (NIS) from Jan. } 2002 \text { to } \\
\text { Dec. } 2014\end{array}$ & $\begin{array}{c}\text { Pregnant women aged } \\
13-49 \text { yrs who had } \\
\text { pregnancy-related inpatient } \\
\text { hospitalizations }(n=153,608 \\
\text { cocaine users; } n=56,882,258 \\
\text { non-drug users) }\end{array}$ & $\begin{array}{c}\text { 0\%, Age group: 13-24 } \\
(21.4 \%) ; 25-34(55.4 \%) ; \\
35-49(20.5 \%) \text { in the } \\
\text { cocaine users' group; } 0 \% \text {, } \\
\text { Age group: 13-24 (34.0\%); } \\
\text { 25-34 (51.3\%); 35-49 } \\
(14.7 \%) \text { in the non-drug } \\
\text { users' group }\end{array}$ & Acute MI or cardiac arrest & $\begin{array}{c}\text { Cocaine use associated with acute MI } \\
\text { or cardiac arrest (adjusted OR }=1.83 \text {, } \\
95 \% \text { CI: } 1.28-2.62)\end{array}$ \\
\hline
\end{tabular}


Table 1. Cont

\begin{tabular}{|c|c|c|c|c|c|c|c|}
\hline Study (year) & Country & Study Design & Data Source & $\begin{array}{l}\text { Study Population } \\
\text { (Sample Size) }\end{array}$ & $\begin{array}{l}\text { Male \%, Age } \\
(\text { mean } \pm \text { SD) }\end{array}$ & Outcome(s) & Findings \\
\hline $\begin{array}{l}\text { Aslibekyan et al. } \\
\text { (2008) [86] }\end{array}$ & US & Retrospective & $\begin{array}{l}\text { National Health and } \\
\text { Nutrition Examination } \\
\text { Survey (NHANES) in } \\
\text { 1988-1994 and 2005-2006 }\end{array}$ & $\begin{array}{l}\text { Civilian non-institutionalized } \\
\text { US adults (a) aged 18-59 } \\
(n=11,993) ;(\text { b) aged 18-45 } \\
(n=9337)\end{array}$ & $\begin{array}{l}\text { (a) } 46 \%, 36 \mathrm{yrs}(\mathrm{N} / \mathrm{R}) ; \\
\text { (b) } 39 \%, 31 \mathrm{yrs}(\mathrm{N} / \mathrm{R})\end{array}$ & Prevalence of MI & $\begin{array}{c}\text { (a) No significant association } \\
\text { between cocaine use and MI in the } \\
18-59 \text { age group; (b) Significant } \\
\text { association between cocaine use of } \\
>10 \text { lifetime instances and MI in the } \\
18-45 \text { age group (aged-adjusted } \\
\text { OR }=4.60,95 \% \text { CI: } 1.12-18.88), \\
\text { but this association was attenuated in } \\
\text { the multivariate-adjusted model } \\
\text { (OR }=3.84,95 \% \text { CI: } 0.98-15.07)\end{array}$ \\
\hline $\begin{array}{l}\text { Gunja et al. } \\
(2018)^{2}[87]\end{array}$ & US & Retrospective & Veterans Affairs database & $\begin{array}{l}\text { Veterans with CAD } \\
\text { undergoing cardiac } \\
\text { catheterization from Oct. } 2007 \\
\text { to Sep. } 2014(n=3082 \text { in the } \\
\text { cocaine group; } n=118,953 \text { in } \\
\text { the non-cocaine group })\end{array}$ & $\begin{array}{l}\text { 98.6\%, median age: } 58 \\
\text { (IQR: } 54-62 \text { ) yrs in the } \\
\text { cocaine group; } 98.6 \% \text {, } \\
\text { median age: } 65 \text { (IQR: } \\
\text { 61-72) yris in the } \\
\text { non-cocaine group }\end{array}$ & $\begin{array}{l}\text { MI and 1-year } \\
\text { all-cause mortality }\end{array}$ & $\begin{array}{c}\text { With adjustment of basic cardiac risk } \\
\text { factors, cocaine use was significantly } \\
\text { associated with MI (HR }=1.40, \\
95 \% \text { CI: } 1.07-1.83 \text { ) and mortality } \\
\text { (HR }=1.23,95 \% \text { CI: } 1.08-1.39) \text {. After } \\
\text { adjustment for risky behaviors, } \\
\text { cocaine use was associated with } \\
\text { mortality (HR }=1.22,95 \% \text { CI: } \\
1.04-1.42) \text {, but not with MI } \\
(\mathrm{HR}=1.17,95 \% \text { CI } 0.87-1.56) \text {. After } \\
\text { adjustment for causal pathway } \\
\text { conditions, mortality was no longer } \\
\text { significant (HR }=1.15 \\
95 \% \text { CI: } 0.99-1.33)\end{array}$ \\
\hline \multicolumn{8}{|c|}{ Chronic effects of cocaine } \\
\hline $\begin{array}{l}\text { Maceira et al. } \\
(2014)[45]\end{array}$ & Spain & Prospective & $\begin{array}{l}\text { Study participants and a } \\
\text { gender and age matched } \\
\text { healthy group }\end{array}$ & $\begin{array}{l}\text { Cocaine abusers attending a } \\
\text { rehabilitation clinic for the } \\
\text { first time }(n=94)\end{array}$ & $86 \%, 37 \pm 7 \mathrm{yrs}$ & $\begin{array}{l}\text { Cocaine cardiotoxicity } \\
\text { using a CMR protocol }\end{array}$ & $\begin{array}{l}\text { Increased LV end-systolic volume, } \\
\mathrm{LV} \text { mass index, and RV end-systolic } \\
\text { volume, and decreased LV ejection } \\
\text { fraction and RV ejection fraction in } \\
\text { cocaine abusers compared with those } \\
\text { in the gender and age matched } \\
\text { healthy group }\end{array}$ \\
\hline $\begin{array}{l}\text { Arora et al. } \\
\text { (2015) [88] }\end{array}$ & US & Cross-sectional & $\begin{array}{l}\text { Drug treatment center } \\
\text { in Florida }\end{array}$ & $\begin{array}{l}\text { Caucasian adults with } \\
\text { cocaine use disorder }(n=33)\end{array}$ & $33 \%, 37 \pm 9$ yrs & $\begin{array}{l}\text { Presence of subclinical } \\
\text { CAD using CIMT }\end{array}$ & $\begin{array}{l}\text { No association between chronic } \\
\text { cocaine use and subclinical CAD } \\
\text { measured by CIMT }\end{array}$ \\
\hline $\begin{array}{l}\text { Bamberg et al. } \\
(2009)[89]\end{array}$ & US & $\begin{array}{l}\text { Nested matched } \\
\text { cohort }\end{array}$ & $\begin{array}{l}\text { Massachusetts } \\
\text { General Hospital }\end{array}$ & $\begin{array}{l}\text { Patients who presented to the } \\
\text { emergency department with } \\
\text { acute chest pain in May to } \\
\text { July, } 2005 \text { ( } n=44 \text { in the } \\
\text { cocaine group; } n=132 \text { in the } \\
\text { non-cocaine group) }\end{array}$ & $\begin{array}{c}86 \%, 46 \pm 7 \text { yrs in the } \\
\text { cocaine group; } 86 \%, \\
46 \pm 7 \text { yrs in the } \\
\text { non-cocaine group }\end{array}$ & $\begin{array}{l}\mathrm{ACS} \text { and CAD using } \\
\text { coronary CT }\end{array}$ & $\begin{array}{c}\text { Significant association of cocaine use } \\
\text { with increased risk of ACS group } \\
(\mathrm{OR}=5.79,95 \% \mathrm{CI}: 1.24-27.02), \\
\text { but no association with } \\
\text { coronary stenosis }\end{array}$ \\
\hline $\begin{array}{l}\text { Chang et al. } \\
\text { (2011) [90] }\end{array}$ & US & Cross-sectional & $\begin{array}{c}\text { University of } \\
\text { Pennsylvania Hospital }\end{array}$ & $\begin{array}{l}\text { Patients who received } \\
\text { coronary CTA for evaluation } \\
\text { of CAD in the emergency } \\
\text { department from May } 2005 \text { to } \\
\text { Dec. } 2008 \text { ( } n=157 \text { in the } \\
\text { cocaine group; } n=755 \text { in the } \\
\text { non-cocaine group) }\end{array}$ & $\begin{array}{l}58 \%, 46 \pm 6 \text { yrs in the } \\
\text { cocaine group; } 40 \% \\
48 \pm 9 \text { yrs in the } \\
\text { non-cocaine group }\end{array}$ & CAD & $\begin{array}{l}\text { No association between recent } \\
\text { cocaine use and the presence of } \\
\text { coronary lesions } \geq 25 \% \text { (adjusted } \\
\text { RR }=0.92,95 \% \text { CI: }: .58-1.45 \text { ) and } \\
\text { coronary lesions } \geq 50 \% \text { (adjusted } \\
\text { RR }=0.96,95 \% \text { CI: } 0.46-2.01 \text { ) }\end{array}$ \\
\hline
\end{tabular}


Table 1. Cont

\begin{tabular}{|c|c|c|c|c|c|c|c|}
\hline Study (year) & Country & Study Design & Data Source & $\begin{array}{l}\text { Study Population } \\
\text { (Sample Size) }\end{array}$ & $\begin{array}{l}\text { Male \%, Age } \\
\text { (mean } \pm \text { SD) }\end{array}$ & Outcome(s) & Findings \\
\hline $\begin{array}{l}\text { Lai et al. } \\
\text { (2016) [91] }\end{array}$ & US & Cross-sectional & Study participants & $\begin{array}{c}\text { African American adults } \\
\text { with } / \text { without HIV infection } \\
\text { in Baltimore ( } n=737 \text { in the } \\
\text { cocaine group; } n=692 \text { in the } \\
\text { non-cocaine group) }\end{array}$ & $\begin{array}{l}60.3 \%, 45 \text { (IQR: } 40-50 \text { ) yrs } \\
\text { in the entire population }\end{array}$ & $\begin{array}{l}\text { Subclinical CAD defined } \\
\text { by the presence of CAC } \\
\text { detected by noncontrast } \\
\text { CT and/or coronary } \\
\text { plaque detected by } \\
\text { contrast-enhanced } \\
\text { coronary CT angiography }\end{array}$ & $\begin{array}{l}\text { Chronic cocaine use associated with } \\
\text { high risk for subclinical CAD } \\
\text { (propensity score-adjusted } \\
\text { prevalence ratio }=1.27,95 \% \text { CI: } \\
\text { 1.08-1.49), CAC (propensity } \\
\text { score-adjusted prevalence ratio=1.26, } \\
95 \% \text { CI: 1.05-1.52), any coronary } \\
\text { stenosis (propensity score-adjusted } \\
\text { prevalenceratio }=1.30,95 \% \text { CI: } \\
\text { 1.08-1.57), and calcified plaques } \\
\text { (propensity score-adjusted } \\
\text { prevalence ratio }=1.37, \\
95 \% \text { CI: } 1.10-1.71 \text { ) }\end{array}$ \\
\hline $\begin{array}{l}\text { Lucas et al. } \\
\text { (2016) [92] }\end{array}$ & US & $\begin{array}{l}\text { Cross-sectional } \\
\text { and longitudinal }\end{array}$ & Study participants & $\begin{array}{c}\text { Adults with/without human } \\
\text { immunodeficiency virus } \\
\text { infection in Baltimore }(n=57 \\
\text { never cocaine users; } n=82 \\
\text { past cocaine userss } n=153 \\
\text { current cocaine users) }\end{array}$ & $\begin{array}{l}\text { 67\%, } 46 \text { (IQR: } 41-53 \text { ) yrs } \\
\text { in the never users; } 66 \%, 51 \\
\text { (IQR: } 46-54 \text { ) yrs in the } \\
\text { past users; } 75 \% \text {, } 49 \\
\text { (IQR: } 45-55 \text { yrs in the } \\
\text { current users }\end{array}$ & $\begin{array}{l}\text { Subclinical CVD: carotid } \\
\text { artery plaque }\end{array}$ & $\begin{array}{c}\text { Cocaine use associated with } \\
\text { approximately three-fold higher } \\
\text { odds of carotid plaques at baseline } \\
\text { (OR }=3.3,95 \% \text { CI: } 1.5-7.3 \text { for past } \\
\text { cocaine users vs. cocaine nonusers; } \\
\text { OR = } 2.7,95 \% \text { CI: } 1.3-5.5 \text { for the } \\
\text { current cocaine users vs. } \\
\text { cocaine nonusers) }\end{array}$ \\
\hline \multicolumn{8}{|c|}{ Cocaine effects on mortality } \\
\hline $\begin{array}{l}\text { DeFilippis et al. } \\
\text { (2018) [93] }\end{array}$ & US & $\begin{array}{l}\text { Retrospective } \\
\text { cohort }\end{array}$ & $\begin{array}{c}\text { Two academic medical } \\
\text { centers (Brigham and } \\
\text { Women's Hospital and } \\
\text { Massachusetts } \\
\text { General Hospital) } \\
\end{array}$ & $\begin{array}{l}\text { Patients presenting with an } \\
\text { MI at } \leq 50 \text { years between } 2000 \\
\text { and } 2016(n=99 \text { in the } \\
\text { cocaine group; } 1873 \text { in the } \\
\text { non-cocaine group) }\end{array}$ & $\begin{array}{l}85 \%, 44 \text { (range: } 40-46 \text { ) yrs } \\
\text { in the cocaine group; } 80 \% \text {, } \\
45 \text { (range: } 42-48 \text { ) yrs in } \\
\text { the non-cocaine group }\end{array}$ & $\begin{array}{l}\text { Cardiovascular mortality } \\
\text { and all-cause mortality }\end{array}$ & $\begin{array}{c}\text { Significant association of cocaine use } \\
\text { with cardiovascular mortality } \\
\text { (HR = 2.32, } 95 \% \text { C C: } 1.11-4.85) \text { and } \\
\text { all-cause mortality }(\mathrm{HR}=1.91 \\
95 \% \text { CI: } 1.11-3.29)\end{array}$ \\
\hline $\begin{array}{l}\text { Morentin et al. } \\
\text { (2014) [94] }\end{array}$ & Spain & $\begin{array}{l}\text { Case-control } \\
\text { retrospective }\end{array}$ & $\begin{array}{l}\text { Forensic autopsy reports } \\
\text { in Biscay, Spain }\end{array}$ & $\begin{array}{c}\text { All SCVD in individuals aged } \\
15-49(n=311) ; \text { SnoCVD } \\
(n=126) \text { from Jan. } 2003 \text { to } \\
\text { Dec. } 2009\end{array}$ & $\begin{array}{c}82 \%, 41 \pm 7 \text { yrs in SCVD; } \\
71 \%, 39 \pm 7 \text { yrs } \\
\text { in SnoCVD }\end{array}$ & Cocaine detected in blood & $\begin{array}{l}\text { Cocaine being the risk for SCVD } \\
(\mathrm{OR}=4.10 ; 95 \% \text { CI: } 1.12-15.0)\end{array}$ \\
\hline $\begin{array}{l}\text { Qureshi et al. } \\
\text { (2014) [95] }\end{array}$ & US & Retrospective & NHANES in 1988-1994 & $\begin{array}{l}\text { Civilian non-institutionalized } \\
\text { US adults aged 18-45 } \\
(n=7751 \text { cocaine nonusers; } \\
n=730 \text { infrequent cocaine } \\
\text { users (1-10 times); } n=354 \\
\text { frequent cocaine users } \\
(>10 \text { times); } n=178 \text { regular } \\
\text { cocaine users }(>100 \text { times) })\end{array}$ & $\begin{array}{l}43 \%, 31 \pm 8 \text { yrs in the } \\
\text { cocaine non-users' group; } \\
59 \%, 31 \pm 10 \text { yrs in the } \\
\text { infrequent cocaine users } \\
\text { group; } 65 \%, 33 \pm 9 \text { yrs in } \\
\text { the frequent cocaine users } \\
\text { group; } ; 0 \%, 33 \pm 7 \text { yrs in } \\
\text { the regular cocaine } \\
\text { users group }\end{array}$ & $\begin{array}{l}\text { Cardiovascular mortality } \\
\text { and all-cause mortality }\end{array}$ & $\begin{array}{c}\text { Regular lifetime cocaine use was } \\
\text { associated with high all-cause } \\
\text { mortality (RR }=1.9,95 \% \text { CI: } 1.2-3.0) \text {, } \\
\text { but not cardiovascular mortality } \\
\text { (RR = 0.6, } 95 \% \text { CI: } 0.1-4.7) \text { compared } \\
\text { with cocaine nonusers }\end{array}$ \\
\hline $\begin{array}{l}\text { Hser et al. } \\
\text { (2012) [96] }\end{array}$ & US & Prospective cohort & $\begin{array}{l}\text { California Treatment } \\
\text { Outcome Project (CalTOP) } \\
\text { between } 2000 \text { and 2002, } \\
\text { the National Death Index } \\
\text { by 2008, the National } \\
\text { Death Register by 2010, } \\
\text { and the California } \\
\text { Department of } \\
\text { Mental Health }\end{array}$ & $\begin{array}{l}\text { Women admitted to } 40 \text { drug } \\
\text { abuse treatment programs } \\
\text { through CalTOP }(n=4,253 \text { for } \\
\text { those alive in 2010; } ;=194 \text { for } \\
\text { those deceased by 2010) }\end{array}$ & $\begin{array}{c}0 \%, 33 \pm 8 \text { yrs for living } \\
0 \% 37 \pm 7 \text { yrs for } \\
\text { the deceased }\end{array}$ & 8 to 10 -year mortality & $\begin{array}{c}\text { Cocaine was associated with higher } \\
\text { mortality relative to } \\
\text { methamphetamine } \mathrm{HR}=3.56 \\
95 \% \text { CI: } 1.95-6.48)\end{array}$ \\
\hline
\end{tabular}


Table 1. Cont

\begin{tabular}{|c|c|c|c|c|c|c|c|}
\hline Study (year) & Country & Study Design & Data Source & $\begin{array}{l}\text { Study Population } \\
\text { (Sample Size) }\end{array}$ & $\begin{array}{l}\text { Male \%, Age } \\
(\text { mean } \pm \text { SD) }\end{array}$ & Outcome(s) & Findings \\
\hline $\begin{array}{l}\text { Atoui et al. } \\
\text { (2011) [97] }\end{array}$ & US & $\begin{array}{l}\text { Retrospective } \\
\text { chart review }\end{array}$ & $\begin{array}{l}\text { Electronic medical records } \\
\text { in Bronx Lebanon } \\
\text { Hospital Center }\end{array}$ & $\begin{array}{c}\text { Patients admitted with chest } \\
\text { pain to the hospital who had } \\
\text { no cardiovascular risk factors } \\
\text { from July } 2009 \text { to June } 2010 \\
\text { ( } n=54 \text { in the cocaine group; } \\
n=372 \text { in the } \\
\text { non-cocaine group) }\end{array}$ & $\begin{array}{l}59 \%, 44 \pm 10 \text { yrs in the } \\
\text { cocaine group; } 49 \%, \\
43 \pm 12 \text { yrs in the } \\
\text { non-cocaine group }\end{array}$ & $\begin{array}{l}\text { Length of stay } \\
\text { and mortality }\end{array}$ & $\begin{array}{l}\text { No significant difference in length of } \\
\text { stay ( } 3.0 \text { vs. } 2.4) \text { and in-hospital } \\
\text { mortality }(0 \% \text { vs. } 1 \%) \text { between the } \\
\text { cocaine group and the } \\
\text { non-cocaine group }\end{array}$ \\
\hline
\end{tabular}

ACS: Acute coronary syndrome; CAA: Coronary artery aneurysm; CAC: Coronary artery calcium; CAD: Coronary artery disease; CI: Confidence interval; CIMT: Carotid intima media thickness; CMR: Cardiovascular magnetic resonance; CT: Computed tomography; CTA: Computerized tomographic angiography; CVD: Cardiovascular disease; ECG: Electrocardiogram; HR: Hazard ratio; IQR: Interquartile range; LV: Left ventricular; MI: Myocardial infarction; N/R: not reported; OR: Odds ratio; RR: Relative risk; RV: Right ventricular; SCVD: Sudden cardiovascular death; SnoCVD: Sudden death not due to cardiovascular diseases; STEMI: ST elevation myocardial infarction. ${ }^{1}$ Including acute effects (i.e., acute STEMI and cardiogenic shock) and chronic effect (i.e., multivessel CAD) of cocaine and mortality as the study outcomes. ${ }^{2}$ Including acute effect of cocaine (i.e., MI) and 1-year all-cause mortality as the study outcomes. 
In addition, Sharma et al. [43] retrospectively reviewed electrocardiogram (ECG) recordings of cocaine-dependent subjects to examine cardiotoxicity of cocaine use. The ECGs were collected from 97 cocaine-dependent subjects aged $50 \pm 4$ years ( $86 \%$ male) in a comprehensive academic health center and 8513 cocaine-non-using subjects aged $52 \pm 5$ years ( $46 \%$ male) participating in the Atherosclerosis Risk in Communities (ARIC) study. The authors found significant effects of cocaine use on early repolarization (odds ratio $(\mathrm{OR})=4.92,95 \%$ confidence interval $(\mathrm{CI}): 2.73-8.87$ ), bradycardia $(\mathrm{OR}=3.02$, 95\% CI: $1.95-4.66)$, severe bradycardia (OR $=5.11,95 \%$ CI: 2.95-8.84), and heart rate (B weight $=-5.84$, 95\% CI: -7.85 to -3.82 ). Recently, there was a case report of Mobitz type II atrioventricular (AV) block associated with cocaine use [82]. This case occurred in a 55-year-old female who presented with chest pain after cocaine use.

Satran et al. [83] investigated the prevalence of CAAs among cocaine users undergoing coronary angiography using a database from a medical center in the US. The study population included 112 patients with a history of cocaine use aged $44 \pm 8$ years (79\% male) and 79 patients with no history of cocaine use aged $46 \pm 5$ years (61\% male). Based on the finding that cocaine users had a significantly higher CAA compared with cocaine non-users ( $30.4 \%$ vs. $7.6 \%$, respectively), the authors concluded that cocaine users were likely to be at increased risk of acute MI.

Several studies examined the association between cocaine use and MI. Gupta et al. [84] examined the incidence of acute ST elevation myocardial infarction (STEMI), cardiogenic shock, multivessel CAD, and in-hospital mortality in the cocaine group $(n=924)$ compared with the non-cocaine group $(n=102,028)$ among patients admitted within $24 \mathrm{~h}$ of acute MI. This study used data from the National Cardiovascular Data Registry Acute Coronary Treatment and Intervention Outcomes Network Registry-Get With The Guidelines (ACTION Registry-GWTG) program. Compared with the non-cocaine group, the cocaine group was younger (average age: 50 (44-56) vs. 64 (54-76)), had a higher proportion of men ( $80 \%$ vs. $65 \%$ ) and African-Americans ( $45 \%$ vs. $9 \%)$, and fewer traditional cardiovascular risk factors such as hypertension ( $65 \%$ vs. $71 \%)$, dyslipidemia ( $42 \%$ vs. $59 \%)$, previous coronary bypass ( $6 \%$ vs. $14 \%$ ), and previous revascularization ( $24 \%$ vs. $31 \%)$. Gupta et al. [84] found higher percentages of STEMI ( $46 \%$ vs. $40 \%)$ and cardiogenic shock $(13 \%$ vs. $4 \%)$ in cocaine users although their percentage of multivessel CAD was lower (53\% vs. $65 \%$ ) compared with cocaine non-users. In-hospital mortality was similar between the two groups (OR =1.00, 95\% CI: 0.69-1.44). Another study conducted by Salihu et al. [85] included pregnant women aged 13-49 years to examine the association of cocaine use with incidence of acute MI or cardiac arrest during pregnancy or childbirth. This retrospective study used data from January 2002 through December 2014 from the National Inpatient Sample (NIS), a large public inpatient database in the U.S. The study results showed that cocaine users $(n=153,608)$ were at higher risk for acute MI or cardiac arrest compared with drug non-users ( $n=56,882,258)$, with adjusted OR of 1.83 (95\% CI: 1.28-2.62). Some studies showed that the association between cocaine use and MI was affected by some confounders such as cardiac risk factors and risky behaviors. For example, Aslibekyan et al. [86] conducted a retrospective study examining the prevalence of MI among civilian non-institutionalized US adults. Using data from the National Health and Nutrition Examination Survey (NHANES), their study included two different age groups for their study population: (a) individuals aged $18-59$ years ( $n=11,993,46 \%$ male) and (b) those aged $18-45$ years ( $n=9337,39 \%$ male). Although Aslibekyan et al. [86] found no association between cocaine use and MI in the 18-59 age group, cocaine use of $>10$ lifetime instances was significantly associated with $\mathrm{MI}$ in the 18-45 age group after adjusting for age (aged-adjusted $\mathrm{OR}=4.60$, 95\% CI: 1.12-18.88). This association was affected by cardiac risk factors (e.g., smoking status, history of diabetes, hyperlipidemia, and hypertension) in the multivariate-adjusted model (OR $=3.84$, 95\% CI: 0.98-15.07). Another retrospective study by Gunja et al. [87] examined the association of cocaine use with MI and 1-year all-cause mortality. The study included veterans with CAD who underwent coronary catheterization between October 2007 and September 2014 using the Veterans Affairs database. Compared with the non-cocaine group $(n=118,953)$, the cocaine group $(n=3082)$ was younger (median age: 58 vs. 65 ), more likely to be African-American (59\% vs. $11 \%$ ) and had fewer 
traditional cardiac risk factors. After adjusting for cardiac risk factors, cocaine use was significantly associated with MI (hazard ratio (HR) $=1.40,95 \%$ CI: 1.07-1.83); however, this association became attenuated after controlling for risky behaviors in the sequential multivariable model $(\mathrm{HR}=1.17$, 95\% CI: 0.87-1.56).

In summary, prior studies have reported that cocaine use was associated with acute cardiovascular conditions such as elevated blood pressure, (severe) bradycardia, CAAs, and acute MI. These findings are consistent with earlier studies documenting cocaine-related MI [59,98]. Of note, the studies in this review suggest that the association between cocaine use and MI might be confounded by cardiac risk factors or risky behaviors. Accordingly, the risk of MI among cocaine users needs to be understood in the context of risk factors and risky behaviors.

\subsection{Chronic Effects of Cocaine}

Several studies examined whether cocaine use was associated with chronic cardiovascular conditions such as cardiomyopathy (e.g., LV hypertrophy), subclinical atherosclerosis, and CAD. In this section, we present the characteristics of each study along with the study findings. We interpreted the results with consideration of study populations and data sources.

Maceira et al. [45] found that cocaine abusers had increased LV end-systolic volume, LV mass index, and right ventricular (RV) end-systolic volume, with decreased LV ejection fraction and RV ejection fraction. The study participants were 94 cocaine abusers aged $37 \pm 7$ years $(86 \%$ male) attending a rehabilitation clinic for the first time. They were compared with an age- and gender-matched healthy group. As previously mentioned, Kozor et al. [81] also showed greater LV mass among regular cocaine users compared with cocaine nonusers.

Furthermore, several previous studies examined the association between cocaine use and CAD. The effects of cocaine on subclinical CAD were examined using different CAD surrogate markers [84,88-91]. For example, Arora et al. [88] examined the presence of subclinical CAD using carotid intima media thickness (CIMT) as a surrogate marker. This cross-sectional study included 33 Caucasian adults aged $37 \pm 9$ years who used cocaine (33\% male). Their findings suggested no association between chronic cocaine use and subclinical CAD measured by CIMT. Another study conducted by Bamberg et al. examined the association of cocaine use with CAD and ACS using coronary computed tomography (CT) [89]. The study subjects were patients who presented to the emergency department (ED) with acute chest pain. In this nested matched cohort study, there were 44 patients in the cocaine group aged $46 \pm 7$ years ( $86 \%$ male) and 132 patients in the age- and gender-matched non-cocaine group. The authors found no significant association between cocaine use and coronary stenosis, but found a significant association between cocaine use and ACS (OR $=5.79$, 95\% CI: 1.24-27.02). Chang et al. [90] conducted another cross-sectional study that included patients who received coronary computerized tomographic angiography (CTA) for evaluation of CAD in the ED. The patients were at low- to intermediate-risk for ACS. Of these patients, cocaine users were aged $46 \pm 6$ years ( $n=157,58 \%$ male) while the non-cocaine group was aged $48 \pm 9$ years ( $n=755,40 \%$ male). Chang et al. [90] found no association between repetitive cocaine use and coronary calcifications or between recent cocaine use and CAD. As noted previously, Gupta et al. [84] investigated the incidence of multivessel CAD in addition to STEMI and cardiogenic shock between the cocaine group $(n=924)$ and the non-cocaine group $(n=102,028)$ among patients admitted within $24 \mathrm{~h}$ of acute MI. They found a lower percentage of multivessel CAD among cocaine users than cocaine nonusers (53\% vs. $65 \%$ ), although the percentages of STEMI ( $46 \%$ vs. $40 \%$ ) and cardiogenic shock ( $13 \%$ vs. $4 \%$ ) were higher. In contrast to these studies, a study by Lai et al. [91] found a higher risk for subclinical CAD among cocaine users compared with cocaine non-users (propensity score-adjusted prevalence ratio $(P R)=1.27$, 95\% CI: 1.08-1.49). The subjects in the study by Lai et al. [91] were African Americans aged 45 years (Interquartile range (IQR): $40-50$ ), of whom $60 \%$ were males. Approximately $67 \%$ of the subjects were HIV-positive. In this cross-sectional study, subclinical CAD was defined by the presence of coronary artery calcium (CAC) detected by non-contrast $\mathrm{CT}$ and/or coronary plaque detected by 
contrast-enhanced CT angiography (CCTA). Chronic cocaine users were at significantly higher risk for the presence of CAC (propensity score-adjusted PR $=1.26,95 \%$ CI: $1.05-1.52$ ), any coronary stenosis (propensity score-adjusted PR $=1.30,95 \%$ CI: 1.08-1.57), and calcified plaques (propensity score-adjusted PR $=1.37,95 \%$ CI: 1.10-1.71), in addition to subclinical CAD. Another study conducted by Lucas et al. [92] showed a significant association between cocaine use and carotid plaque formation. More than $90 \%$ of subjects in this study were African Americans. Cocaine non-users were aged 46 years (IQR: $41-53$ ), and $67 \%$ were male. Past cocaine users were aged 51 years (IQR: $46-54$ ), and 66\% were male. Current cocaine users were aged 49 years (IQR: 45-52), and 75\% were male. Of the study subjects, approximately $66 \%$ were HIV-positive. Compared with cocaine non-users, both past cocaine users and current users had approximately three-fold higher odds of having carotid plaques at baseline (OR $=3.3,95 \%$ CI: $1.5-7.3$ and $\mathrm{OR}=2.7,95 \%$ CI: $1.3-5.5$, respectively).

In summary, cocaine was reported to be associated with high risk for cardiomyopathy characterized by LV hypertrophy [45,81] and ACS [89]. In particular, one study found an approximately six-fold higher risk for ACS among cocaine users [89]. However, studies have reported inconsistent findings regarding association between cocaine use and subclinical CAD. Some studies found no association of cocaine use with coronary calcifications [88-90]. This result is consistent with findings in the Coronary Artery Risk Development in Young Adults (CARDIA) study which examined the association between cocaine exposure and prevalence of coronary calcification by including over 3000 participants [99]. The CARDIA study reported no relationship between cocaine exposure and coronary calcium after adjusting for age, sex, ethnicity, socioeconomic status, family history, tobacco use, and alcohol use. However, Lai et al. [91] reported that cocaine use was associated with subclinical coronary atherosclerosis. Lai et al. [95-97] also showed this association in their earlier studies. Similarly, Lucas et al. [92] found greater carotid plaque formation at baseline among cocaine users compared with cocaine nonusers. This variability in findings across studies regarding association between cocaine use and subclinical CAD might be explained by different CAD risk factor profiles of the study populations. The studies reporting cocaine-associated plaques included predominantly African American participants, of whom $40 \%$ to $100 \%$ were HIV-positive [91,92,100-102]. In contrast, all other studies showing no association between cocaine use and coronary calcifications did not include any HIV-positive individuals [84,88-90]. It has been widely known that HIV infection is a risk factor for CAD. Therefore, the study subjects with HIV may have been at higher risk for development of CAD, as was pointed by Arora et al. [88].

\subsection{Effects of Cocaine on Mortality}

Several studies estimated cardiovascular mortality among cocaine users. These studies have shown mixed results with regard to association of cocaine use with cardiovascular mortality. Some studies have reported higher risk for cardiovascular mortality among cocaine users compared with cocaine non-users. For example, DeFilippis et al. [93] retrospectively analyzed records of patients with MI at $\leq 50$ years of age between 2000 and 2016 to examine the risk of cocaine use for cardiovascular mortality and all-cause mortality. Patient data were obtained from two large academic medical centers in the US There were 99 individuals in the cocaine-group (mean age: 44 (40-46), 85\% male) and 1873 individuals in the non-cocaine group (mean age: 45 (42-48), 80\% male). The authors found significant associations of cocaine use with cardiovascular mortality (HR=2.32, 95\% CI: 1.11-4.85) and all-cause mortality ( $\mathrm{HR}=1.91,95 \% \mathrm{CI}: 1.11-3.29)$. In Spain, Morentin et al. [94] investigated the prevalence of recent cocaine use in individuals who had died by sudden cardiovascular death (SCVD) between January 2003 and December $2009(n=311)$. The mean age was $41 \pm 7$ years, and $82 \%$ were male. Individuals who had died by sudden deaths not due to cardiovascular diseases (SnoCVD) served as the control group $(n=126)$. The average age and percentage of males in the control group were $39 \pm 7$ years and $71 \%$. The authors found that recent cocaine use was a significant risk factor for SCVD $(\mathrm{OR}=4.10,95 \% \mathrm{CI}: 1.12-15.0)$. In contrast, Qureshi et al. [95] found that regular cocaine use was not associated with cardiovascular mortality (relative risk $(R R)=0.6,95 \%$ CI: $0.1-4.7$ ). The study subjects 
in this retrospective study were civilian non-institutionalized US adults aged $18-45$ in the NHANES dataset. The study included 7751 cocaine nonusers (mean age: $31 \pm 8$ years, $43 \%$ males) and 178 regular cocaine users (lifetime cocaine use $>100$ times) (mean age: $33 \pm 7$ years, $70 \%$ males). Although the study results showed a significant association between regular cocaine use and all-cause mortality $(\mathrm{RR}=1.9,95 \% \mathrm{CI}: 1.2-3.0)$, regular cocaine use was not associated with cardiovascular mortality.

Prior studies examining the association of cocaine use with all-cause mortality have also reported inconsistent findings. In some studies, cocaine use was significantly associated with all-cause mortality. As mentioned previously, DeFilippis et al. [93] and Qureshi et al. [95] found an approximately two-fold higher all-cause mortality among cocaine users compared with cocaine nonusers. Similarly, Hser et al. [96] found an elevated mortality risk associated with cocaine use relative to methamphetamine use ( $\mathrm{HR}=3.56,95 \% \mathrm{CI}$ : 1.95-6.48). The subjects in this study were women admitted to drug abuse treatment programs in the US between 2000 and 2002. Contrary to the findings of these studies, some studies have reported no significant association between in-hospital mortality and cocaine use [84,97]. Atoui et al. [97] conducted a retrospective chart review of patients admitted with chest pain to a US-based hospital between July 2009 and June 2010. Of the study population with no risk factors for CAD, 54 were cocaine users (mean age $=44 \pm 10$ years, $59 \%$ males) and 372 were cocaine non-users (mean age $=43 \pm 12$ years, $49 \%$ males). The study results showed no significant differences in length of stay and in-hospital mortality between cocaine users and nonusers. Similarly, in the aforementioned study by Gupta et al. [84] in-hospital mortality was not significantly different between the cocaine group and the non-cocaine group $(\mathrm{OR}=1.00$, 95\% CI: 0.69-1.44). As mentioned previously, in the study by Gunja et al. [87] cocaine use was initially found to be significantly associated with 1-year all-cause mortality after adjusting for cardiac risk factors and risky behaviors among veterans with CAD (HR $=1.22$, 95\% CI: 1.04-1.42) [87]. However, after controlling for causal pathway conditions, mortality was no longer significantly associated with cocaine use (HR: 1.15, 95\% CI: 0.99-1.33).

In summary, some prior studies have reported an association between cocaine use and cardiovascular or all-cause mortality $[93,94,96]$. However, this association was not observed in other studies [84,97]. Variations in findings across studies may be driven by heterogeneity in patient characteristics (e.g., age), risky behaviors (e.g., smoking, alcohol, or other illicit drug use), and traditional risk factors (e.g., morbidities), all of which are predictors of mortality. Indeed, the study by Gunja et al. [87] showed how the association between cocaine use and mortality was confounded by these factors. In their study, cocaine was initially found to be associated with increased all-cause mortality. However, this association was no longer observed after controlling for causal pathway conditions such as congestive heart failure, cardiogenic shock, dialysis, depression, anxiety, ACS, and clinical status. This finding suggests that the effects of cocaine on mortality are largely dependent on individual clinical risk factors. Notably, mortality risk was not significantly higher among cocaine users if the cocaine users had fewer risk factors compared with cocaine nonusers. For example, subjects in the studies performed by Atoui et al. [97] and Gupta et al. [84] were individuals at low risk for CVD and young adults with few CV risk factors, respectively. Both studies found no association between cocaine use and mortality. In contrast, the subjects in studies reporting an association between cocaine use and mortality were at higher risk. The presence of risk factors is likely to augment the risk of mortality following cocaine use. Furthermore, frequency of cocaine use could be an important factor affecting mortality risk among cocaine users. As observed in the study by Qureshi et al., all-cause mortality was about two times higher among regular cocaine users (lifetime cocaine use $>100$ times) compared with cocaine nonusers [95]. However, all cause-mortality of infrequent cocaine users (lifetime cocaine use: $1-10$ times) or frequent cocaine users (lifetime cocaine use $>10$ times) was not significantly different from that of cocaine nonusers in this study. 


\section{Cocaine and Nutrition}

Cocaine use/abuse often affects food intake behavior and suppresses appetite, which may lead to the disruption of metabolic and neuroendocrine regulation. In addition, cocaine-induced malnutrition may decrease levels of neurotransmitters, and alter amino acid absorption and utilization. As such, chronic exposure to cocaine can result in an increased risk of health conditions such as hypertension, body weight problems, diabetes, and metabolic syndrome.

Cocaine affects appetite and body weight through multifactorial mechanisms. As mentioned previously, cocaine inhibits the reuptake of dopamine by interacting with the dopamine transporter, resulting in increased levels of dopamine in the central nervous system. Subsequently, changes in dopamine levels affect eating behavior and body weight [103-105]. Increased dopaminergic neurotransmission suppresses overall food intake whereas it increases fat-rich food intake [106]. In addition, cocaine blocks the reuptake of serotonin by interacting with the serotonin transporter, inducing leptin-dependent anorexic effect $[107,108]$. Prior studies demonstrated that cocaine also upregulated neuromodulators such as cocaine- and amphetamine-regulated transcript (CART), which plays an important role in regulating food intake, maintaining body weight, and in endocrine and cardiovascular functions $[109,110]$. Overexpression of CART has been reported to decrease food intake and change lipid metabolism related to fat storage [111,112].

In accordance with these mechanisms, several pre-clinical studies have shown the effects of cocaine on food consumption and the nutritional status in animals [113-115]. For example, Balopole et al. [113] reported a decrease in food intake after cocaine administration to rats (10, 15, and $25 \mathrm{mg} / \mathrm{kg}$ ). They found that the cocaine-induced anorexia was transient and dose-dependent. After an hour of anorexic effect, it was shown that animals overconsumed foods. Therefore, total food intake was not significantly different between cocaine- and saline-exposed rats. Another study examined the effects of cocaine on the milk intake and body weight in rats [114]. Findings of this study suggested that cocaine disrupted ingestion primarily by interfering with the appetitive phase of feeding behavior (orientation and approach to food) rather than the consummatory phase (ingestion of food). A study by Church et al. [115] examined the effects of prenatal cocaine exposure on maternal/fetal toxicity in animals. Cocaine treatments in rats $(20,30,40$, and $50 \mathrm{mg} / \mathrm{kg})$ resulted in significant reductions in the maternal weight gain and food consumption in a dose-dependent manner. Undernutrition led to a significant reduction in fetal weight. However, maternal water consumption was significantly increased in the cocaine-exposed animals possibly because of the increased locomotor activity and diuretic effect. Furthermore, cocaine provoked diarrhea in some of animals that received high doses, suggesting that cocaine, as a gastrointestinal irritant, might cause malabsorption and loss of electrolytes and nutrients, which ultimately can lead to malnutrition.

Human studies have also shown cocaine's anorexigenic effects and the resulting weight reduction in cocaine users [116,117]. Low caloric intake, together with abnormal metabolic and gastrointestinal functions, can lead to malnutrition among cocaine users [118]. For example, Escobar et al. [119] found that hemoglobin and hematocrit levels in cocaine users were below normal, indicating protein-energy malnutrition and anemia. As the authors pointed out, anemia in this population might be associated with a diet poor in micronutrients (e.g., iron), inadequate protein consumption, and clinical issues such as decreased intrinsic factor secretion, intestinal perforations, and bacterial or infectious diseases. Indeed, three cases were reported where patients required surgery for their intestinal perforations after cocaine use [120]. Cocaine led to mesenteric vasoconstriction and focal tissue ischemia by blocking the reuptake of norepinephrine, which might lead to intestinal perforations. Cocaine users in the study by Escobar et al. were also found to have altered lipid and glucose profiles, with low levels of high density lipoprotein (HDL) cholesterol and high levels of triglycerides, LDL cholesterol, total cholesterol, and glucose. These findings suggested that cocaine users might be at a high risk for metabolic and cardiovascular problems. Of note, cocaine users did not experience weight gain despite a compensatory increase in fat consumption following the cocaine-induced anorexia [117]. However, the cessation of cocaine use resulted in weight gain [117,121]. In a study by Ersche et al., cocaine 
users consumed significantly more fatty foods and carbohydrates compared with cocaine nonusers, but there was no concomitant weight increase in the cocaine group [117]. The authors suggested that an imbalance between fat intake and storage could lead to weight gain among cocaine users when they stop using cocaine. This imbalance might result from metabolic alterations from repeated cocaine use. It is well-known that weight gain increases the risk of cardio-metabolic disorders such as diabetes and cardiovascular conditions [122]. Therefore, weight control, as a means to prevent and lessen cardiovascular diseases, has profound implications during cocaine abstinence.

In summary, cocaine use affects eating behavior and suppresses appetite, leading to malnutrition and anorexia through disruption of the metabolic process and neuroendocrine regulation. Also, cocaine uptake in the body can lead to mesenteric vasoconstriction and focal tissue ischemia, and alter lipid as well as glucose profiles, presumably resulting in increased risk for metabolic and cardiovascular problems in cocaine users. Notably, the cessation of cocaine use causes sudden/excess weight gain during the recovery period/process, leading to increased cardiovascular and cardio-metabolic risks. As such, cocaine-induced changes in food intake patterns and the metabolic process can lead to cardiovascular complications during addiction as well as cessation periods.

\section{Conclusions}

Cocaine use/abuse has been known to make changes in nutrient status and metabolism, which can result in an increased risk of long-term health conditions including eating disorders, metabolic syndrome, and psychological abnormalities. In this review, we focus the deleterious acute and chronic effects of cocaine use particularly on cardiovascular outcomes. We summarized the pathophysiological mechanisms of cocaine on cardiovascular health, which were multifactorial and complex. Compared to chronic effects, acute effects of cocaine have been well-characterized in previous studies. Use of cocaine, a potent cardiovascular stimulant, has been associated with electrocardiographic abnormalities, elevated blood pressure, arrhythmia, and acute MI. The risk of MI among cocaine users was particularly influenced by individuals' cardiac risk factors and risky behaviors. Cocaine use can lead to acute conditions in a multifactorial fashion, for example, by blocking sodium/potassium channels in the heart and enhancing coronary artery spasm/vasoconstriction in vessels. In contrast, chronic effects of cocaine are difficult to determine as evidenced by inconsistent findings across previous studies. Some studies have reported an association of chronic cocaine use with coronary atherosclerosis using coronary calcification as a marker. Conversely, other studies have demonstrated no association between chronic cocaine use and coronary calcification. Of note, the subjects included in studies showing this association were at higher risk for CAD compared with those in the studies that reported no association. Therefore, chronic effects of cocaine may have been more prominent among those with higher CAD risk factor profiles. Contributions of cocaine to chronic conditions were also multifaceted. Long-term exposure to cocaine can exert chronic effects, for example, on the heart through non-ischemic myocardial depression and vessels by inducing endothelial cell injury and intracoronary thrombosis. Furthermore, prior studies suggested that risky behaviors, risk factors for CVD, and frequency of cocaine use may contribute to association between cocaine use and mortality. To evaluate the effects of long-term cocaine use on atherosclerosis and mortality more precisely, large, well-designed longitudinal studies are required with subjects from both low and high-risk populations. $\beta$-blocker therapy has often been suggested for cocaine users, in particular, for those with cocaine-associated heart failure. Studies have shown $\beta$-blockers lowered blood pressure, improved LV ejection fraction, and reduced the incidence of MI and mortality among cocaine users [123-125]. Understanding the multifactorial pathophysiological mechanisms of cocaine could help clinicians recognize the various symptoms after cocaine use/abuse and improve treatment of patients with either acute or chronic symptoms. The various deleterious CV outcomes resulting from cocaine use highlight the need for education regarding adverse cardiac effects of cocaine use, and access to effective interventions for cocaine abusers. Concurrently, alterations in lifestyle and behaviors (e.g., alcohol abuse or tobacco use) are also important for reducing the harmful adverse cardiac effects that these behavioral factors contribute to among cocaine users. 
Author Contributions: Both S.T.K. and T.P. conceptualized and designed the study, extracted and interpreted the data, drafted the manuscript, and approved the final version of the manuscript.

Funding: This research received no external funding.

Conflicts of Interest: The authors declare no conflict of interest.

\section{References}

1. Cornish, J.W.; O'Brien, C.P. Crack cocaine abuse: An epidemic with many public health consequences. Annu. Rev. Public Health 1996, 17, 259-273. [CrossRef] [PubMed]

2. World Drug Report 2018. Available online: https://www.unodc.org/wdr2018/prelaunch/WDR18_Booklet_ 3_DRUG_MARKETS.pdf (accessed on 29 October 2018).

3. Behavioral Health Trends in the United States: Results from the 2014 National Survey on Drug Use and Health. Available online: https:/ / www.samhsa.gov/data/sites/default/files/NSDUH-FRR1-2014/ NSDUH-FRR1-2014.pdf (accessed on 29 October 2018).

4. Egred, M.; Davis, G.K. Cocaine and the heart. Postgrad. Med. J. 2005, 81, 568-571. [CrossRef]

5. De Giorgi, A.; Fabbian, F.; Pala, M.; Bonetti, F.; Babini, I.; Bagnaresi, I.; Manfredini, F.; Portaluppi, F.; Mikhailidis, D.P.; Manfredini, R. Cocaine and acute vascular diseases. Curr. Drug Abuse Rev. 2012, 5, 129-134. [CrossRef]

6. Lange, R.A.; Hillis, L.D. Cardiovascular complications of cocaine use. N. Engl. J. Med. 2001, 345, 351-358. [CrossRef]

7. Trends in Substance Use Disorders among Adults Aged 18 or Older. Available online: https:/ /www.samhsa. gov / data/sites / default/files/report_2790/ShortReport-2790.html (accessed on 11 November 2018).

8. Drug Abuse Warning Network Trends Tables, 2011 Update. Available online: https:/ / www.samhsa.gov/ data/sites/default/files/DAWN2k11ED/DAWN2k11ED/rpts/DAWN2k11-Trend-Tables.htm (accessed on 11 November 2018).

9. Vongpatanasin, W.; Mansour, Y.; Chavoshan, B.; Arbique, D.; Victor, R.G. Cocaine stimulates the human cardiovascular system via a central mechanism of action. Circulation 1999, 100, 497-502. [CrossRef] [PubMed]

10. Howell, L.L.; Carroll, F.I.; Votaw, J.R.; Goodman, M.M.; Kimmel, H.L. Effects of combined dopamine and serotonin transporter inhibitors on cocaine self-administration in rhesus monkeys. J. Pharmacol. Exp. Ther. 2007, 320, 757-765. [CrossRef] [PubMed]

11. Schwartz, B.G.; Rezkalla, S.; Kloner, R.A. Cardiovascular effects of cocaine. Circulation 2010, 122, $2558-2569$. [CrossRef] [PubMed]

12. Pennings, E.J.; Leccese, A.P.; Wolff, F.A. Effects of concurrent use of alcohol and cocaine. Addiction 2002, 97, 773-783. [CrossRef]

13. Rezkalla, S.H.; Kloner, R.A. Cocaine-induced acute myocardial infarction. Clin. Med. Res. 2007, 5, $172-176$. [CrossRef]

14. Davies, O.; Ajayeoba, O.; Kurian, D. Coronary artery spasm: An often overlooked diagnosis. Niger. Med. J. 2014, 55, 356-358. [CrossRef]

15. Talarico, G.P.; Crosta, M.L.; Giannico, M.B.; Summaria, F.; Calo, L.; Patrizi, R. Cocaine and coronary artery diseases: A systematic review of the literature. J. Cardiovasc. Med. 2017, 18, 291-294. [CrossRef] [PubMed]

16. Wilbert-Lampen, U.; Seliger, C.; Zilker, T.; Arendt, R.M. Cocaine increases the endothelial release of immunoreactive endothelin and its concentrations in human plasma and urine: Reversal by coincubation with sigma-receptor antagonists. Circulation 1998, 98, 385-390. [CrossRef]

17. Togna, G.I.; Graziani, M.; Russo, P.; Caprino, L. Cocaine toxic effect on endothelium-dependent vasorelaxation: An in vitro study on rabbit aorta. Toxicol. Lett. 2001, 123, 43-50. [CrossRef]

18. Mo, W.; Singh, A.K.; Arruda, J.A.; Dunea, G. Role of nitric oxide in cocaine-induced acute hypertension. Am. J. Hypertens. 1998, 11, 708-714. [CrossRef]

19. Perreault, C.L.; Morgan, K.G.; Morgan, J.P. Effects of cocaine on intracellular calcium handling in cardiac and vascular smooth muscle. NIDA Res. Monogr. 1991, 108, 139-153. [PubMed]

20. Scholz, A. Mechanisms of (local) anaesthetics on voltage-gated sodium and other ion channels. Br. J. Anaesth. 2002, 89, 52-61. [CrossRef] 
21. Siegel, A.J.; Sholar, M.B.; Mendelson, J.H.; Lukas, S.E.; Kaufman, M.J.; Renshaw, P.F.; McDonald, J.C.; Lewandrowski, K.B.; Apple, F.S.; Stec, J.J.; et al. Cocaine-induced erythrocytosis and increase in von Willebrand factor: Evidence for drug-related blood doping and prothrombotic effects. Arch. Intern. Med. 1999, 159, 1925-1929. [CrossRef] [PubMed]

22. Crumb, W.J., Jr.; Clarkson, C.W. Characterization of cocaine-induced block of cardiac sodium channels. Biophys. J. 1990, 57, 589-599. [CrossRef]

23. Hoffman, R.S. Treatment of patients with cocaine-induced arrhythmias: Bringing the bench to the bedside. Br. J. Clin. Pharmacol. 2010, 69, 448-457. [CrossRef]

24. Williams, M.J.; Restieaux, N.J.; Low, C.J. Myocardial infarction in young people with normal coronary arteries. Heart 1998, 79, 191-194. [CrossRef]

25. Xu, Y.Q.; Crumb, W.J., Jr.; Clarkson, C.W. Cocaethylene, a metabolite of cocaine and ethanol, is a potent blocker of cardiac sodium channels. J. Pharmacol. Exp. Ther. 1994, 271, 319-325.

26. Goldstein, R.A.; DesLauriers, C.; Burda, A.; Johnson-Arbor, K. Cocaine: History, social implications, and toxicity: A review. Semin. Diagn. Pathol. 2009, 26, 10-17. [CrossRef]

27. O'Leary, M.E. Inhibition of HERG potassium channels by cocaethylene: A metabolite of cocaine and ethanol. Cardiovasc. Res. 2002, 53, 59-67. [CrossRef]

28. Ferreira, S.; Crumb, W.J., Jr.; Carlton, C.G.; Clarkson, C.W. Effects of cocaine and its major metabolites on the HERG-encoded potassium channel. J. Pharmacol. Exp. Ther. 2001, 299, 220-226. [PubMed]

29. O'Leary, M.E.; Hancox, J.C. Role of voltage-gated sodium, potassium and calcium channels in the development of cocaine-associated cardiac arrhythmias. Br. J. Clin. Pharmacol. 2010, 69, 427-442. [CrossRef] [PubMed]

30. Crandall, C.G.; Vongpatanasin, W.; Victor, R.G. Mechanism of cocaine-induced hyperthermia in humans. Ann. Intern. Med. 2002, 136, 785-791. [CrossRef]

31. Catravas, J.D.; Waters, I.W. Acute cocaine intoxication in the conscious dog: Studies on the mechanism of lethality. J. Pharmacol. Exp. Ther. 1981, 217, 350-356. [PubMed]

32. Bachi, K.; Mani, V.; Jeyachandran, D.; Fayad, Z.A.; Goldstein, R.Z.; Alia-Klein, N. Vascular disease in cocaine addiction. Atherosclerosis 2017, 262, 154-162. [CrossRef]

33. Mouhaffel, A.H.; Madu, E.C.; Satmary, W.A.; Fraker, T.D., Jr. Cardiovascular complications of cocaine. Chest 1995, 107, 1426-1434. [CrossRef]

34. Lange, R.A.; Cigarroa, R.G.; Yancy, C.W., Jr.; Willard, J.E.; Popma, J.J.; Sills, M.N.; McBride, W.; Kim, A.S.; Hillis, L.D. Cocaine-induced coronary-artery vasoconstriction. N. Engl. J. Med. 1989, 321, 1557-1562. [CrossRef]

35. Sandoval, Y.; Smith, S.W.; Thordsen, S.E.; Apple, F.S. Supply/demand type 2 myocardial infarction: Should we be paying more attention? J. Am. Coll. Cardiol. 2014, 63, 2079-2087. [CrossRef]

36. Pradhan, L.; Mondal, D.; Chandra, S.; Ali, M.; Agrawal, K.C. Molecular analysis of cocaine-induced endothelial dysfunction: Role of endothelin-1 and nitric oxide. Cardiovasc. Toxicol. 2008, 8, 161-171. [CrossRef] [PubMed]

37. Bohm, F.; Pernow, J. The importance of endothelin-1 for vascular dysfunction in cardiovascular disease. Cardiovasc. Res. 2007, 76, 8-18. [CrossRef] [PubMed]

38. Previtali, E.; Bucciarelli, P.; Passamonti, S.M.; Martinelli, I. Risk factors for venous and arterial thrombosis. Blood Transfus. 2011, 9, 120-138.

39. Badimon, L.; Padro, T.; Vilahur, G. Atherosclerosis, platelets and thrombosis in acute ischaemic heart disease. Eur. Heart J. Acute Cardiovasc. Care 2012, 1, 60-74. [CrossRef]

40. Wright, N.M.; Martin, M.; Goff, T.; Morgan, J.; Elworthy, R.; Ghoneim, S. Cocaine and thrombosis: A narrative systematic review of clinical and in-vivo studies. Subst. Abuse Treat. Prev. Policy 2007, 2, 1-8. [CrossRef] [PubMed]

41. Kalogeris, T.; Baines, C.P.; Krenz, M.; Korthuis, R.J. Cell biology of ischemia/reperfusion injury. Int. Rev. Cell Mol. Biol. 2012, 298, 229-317.

42. Graziani, M.; Antonilli, L.; Togna, A.R.; Grassi, M.C.; Badiani, A.; Saso, L. Cardiovascular and hepatic toxicity of cocaine: Potential beneficial effects of modulators of oxidative stress. Oxid. Med. Cell Longev. 2016. [CrossRef]

43. Flores, E.D.; Lange, R.A.; Cigarroa, R.G.; Hillis, L.D. Effect of cocaine on coronary artery dimensions in atherosclerotic coronary artery disease: Enhanced vasoconstriction at sites of significant stenoses. J. Am. Coll. Cardiol. 1990, 16, 74-79. [CrossRef] 
44. Howard, R.E.; Hueter, D.C.; Davis, G.J. Acute myocardial infarction following cocaine abuse in a young woman with normal coronary arteries. JAMA 1985, 254, 95-96. [CrossRef]

45. Maceira, A.M.; Ripoll, C.; Cosin-Sales, J.; Igual, B.; Gavilan, M.; Salazar, J.; Belloch, V.; Pennell, D.J. Long term effects of cocaine on the heart assessed by cardiovascular magnetic resonance at 3T. J. Cardiovasc. Magn. Reson. 2014, 16, 26. [CrossRef] [PubMed]

46. Hale, S.L.; Alker, K.J.; Rezkalla, S.; Figures, G.; Kloner, R.A. Adverse effects of cocaine on cardiovascular dynamics, myocardial blood flow, and coronary artery diameter in an experimental model. Am. Heart J. 1989, 118, 927-933. [CrossRef]

47. Pitts, W.R.; Vongpatanasin, W.; Cigarroa, J.E.; Hillis, L.D.; Lange, R.A. Effects of the intracoronary infusion of cocaine on left ventricular systolic and diastolic function in humans. Circulation 1998, 97, 1270-1273. [CrossRef]

48. Hale, S.L.; Alker, K.J.; Rezkalla, S.H.; Eisenhauer, A.C.; Kloner, R.A. Nifedipine protects the heart from the acute deleterious effects of cocaine if administered before but not after cocaine. Circulation 1991, 83, 1437-1443. [CrossRef] [PubMed]

49. Gardin, J.M.; Wong, N.; Alker, K.; Hale, S.L.; Paynter, J.; Knoll, M.; Jamison, B.; Patterson, M.; Kloner, R.A. Acute cocaine administration induces ventricular regional wall motion and ultrastructural abnormalities in an anesthetized rabbit model. Am. Heart J. 1994, 128, 1117-1129. [CrossRef]

50. Restrepo, C.S.; Rojas, C.A.; Martinez, S.; Riascos, R.; Marmol-Velez, A.; Carrillo, J.; Vargas, D. Cardiovascular complications of cocaine: Imaging findings. Emerg. Radiol. 2009, 16, 11-19. [CrossRef]

51. Cooper, C.J.; Said, S.; Alkhateeb, H.; Rodriguez, E.; Trien, R.; Ajmal, S.; Blandon, P.A.; Hernandez, G.T. Dilated cardiomyopathy secondary to chronic cocaine abuse: A case report. BMC Res. Notes 2013, 6, 536. [CrossRef]

52. Phillips, K.; Luk, A.; Soor, G.S.; Abraham, J.R.; Leong, S.; Butany, J. Cocaine cardiotoxicity: A review of the pathophysiology, pathology, and treatment options. Am. J. Cardiovasc. Drugs 2009, 9, 177-196. [CrossRef]

53. Felker, G.M.; Hu, W.; Hare, J.M.; Hruban, R.H.; Baughman, K.L.; Kasper, E.K. The spectrum of dilated cardiomyopathy. The Johns Hopkins experience with 1,278 patients. Medicine (Baltimore) 1999, 78, 270-283. [CrossRef]

54. Brickner, M.E.; Willard, J.E.; Eichhorn, E.J.; Black, J.; Grayburn, P.A. Left ventricular hypertrophy associated with chronic cocaine abuse. Circulation 1991, 84, 1130-1135. [CrossRef]

55. Nahas, G.G.; Trouve, R.; Manger, W.M. Cocaine, catecholamines and cardiac toxicity. Acta. Anaesthesiol. Scand. Suppl. 1990, 94, 77-81. [CrossRef]

56. Kloner, R.A.; Hale, S.; Alker, K.; Rezkalla, S. The effects of acute and chronic cocaine use on the heart. Circulation 1992, 85, 407-419. [CrossRef] [PubMed]

57. Kolodgie, F.D.; Virmani, R.; Cornhill, J.F.; Herderick, E.E.; Smialek, J. Increase in atherosclerosis and adventitial mast cells in cocaine abusers: An alternative mechanism of cocaine-associated coronary vasospasm and thrombosis. J. Am. Coll. Cardiol. 1991, 17, 1553-1560. [CrossRef]

58. Patrizi, R.; Pasceri, V.; Sciahbasi, A.; Summaria, F.; Rosano, G.M.; Lioy, E. Evidence of cocaine-related coronary atherosclerosis in young patients with myocardial infarction. J. Am. Coll. Cardiol. 2006, 47, 2120-2122. [CrossRef] [PubMed]

59. Minor, R.L., Jr.; Scott, B.D.; Brown, D.D.; Winniford, M.D. Cocaine-induced myocardial infarction in patients with normal coronary arteries. Ann. Intern. Med. 1991, 115, 797-806. [CrossRef] [PubMed]

60. Havranek, E.P.; Nademanee, K.; Grayburn, P.A.; Eichhorn, E.J. Endothelium-dependent vasorelaxation is impaired in cocaine arteriopathy. J. Am. Coll. Cardiol. 1996, 28, 1168-1174. [CrossRef]

61. Gan, X.; Zhang, L.; Berger, O.; Stins, M.F.; Way, D.; Taub, D.D.; Chang, S.L.; Kim, K.S.; House, S.D.; Weinand, M.; et al. Cocaine enhances brain endothelial adhesion molecules and leukocyte migration. Clin. Immunol. 1999, 91, 68-76. [CrossRef]

62. Simpson, R.W.; Edwards, W.D. Pathogenesis of cocaine-induced ischemic heart disease. Autopsy findings in a 21-year-old man. Arch. Pathol. Lab. Med. 1986, 110, 479-484.

63. Shah, P.K. Mechanisms of plaque vulnerability and rupture. J. Am. Coll. Cardiol. 2003, 41 (Suppl. S4), 15S-22S. [CrossRef]

64. Lindstedt, K.A.; Mayranpaa, M.I.; Kovanen, P.T. Mast cells in vulnerable atherosclerotic plaques-A view to a kill. J. Cell. Mol. Med. 2007, 11, 739-758. [CrossRef] 
65. Kokkonen, J.O.; Kovanen, P.T. Stimulation of mast cells leads to cholesterol accumulation in macrophages in vitro by a mast cell granule-mediated uptake of low density lipoprotein. Proc. Natl. Acad. Sci. USA 1987, 84, 2287-2291. [CrossRef]

66. Kokkonen, J.O.; Kovanen, P.T. Proteolytic enzymes of mast cell granules degrade low density lipoproteins and promote their granule-mediated uptake by macrophages in vitro. J. Biol. Chem. 1989, 264, 10749-10755.

67. Huang, M.; Pang, X.; Letourneau, R.; Boucher, W.; Theoharides, T.C. Acute stress induces cardiac mast cell activation and histamine release, effects that are increased in Apolipoprotein E knockout mice. Cardiovasc. Res. 2002, 55, 150-160. [CrossRef]

68. Bohm, M.; La Rosee, K.; Schwinger, R.H.; Erdmann, E. Evidence for reduction of norepinephrine uptake sites in the failing human heart. J. Am. Coll. Cardiol. 1995, 25, 146-153. [CrossRef]

69. Billman, G.E. Cocaine: A review of its toxic actions on cardiac function. Crit. Rev. Toxicol. 1995, 25, 113-132. [CrossRef]

70. Hobbs, W.E.; Moore, E.E.; Penkala, R.A.; Bolgiano, D.D.; Lopez, J.A. Cocaine and specific cocaine metabolites induce von Willebrand factor release from endothelial cells in a tissue-specific manner. Arterioscler. Thromb. Vasc. Biol. 2013, 33, 1230-1237. [CrossRef]

71. Heesch, C.M.; Wilhelm, C.R.; Ristich, J.; Adnane, J.; Bontempo, F.A.; Wagner, W.R. Cocaine activates platelets and increases the formation of circulating platelet containing microaggregates in humans. Heart 2000, 83, 688-695. [CrossRef]

72. Moons, A.H.; Levi, M.; Peters, R.J. Tissue factor and coronary artery disease. Cardiovasc. Res. 2002, 53, $313-325$. [CrossRef]

73. Gu, X.; Herrera, G.A. Thrombotic microangiopathy in cocaine abuse-associated malignant hypertension: Report of 2 cases with review of the literature. Arch. Pathol. Lab. Med. 2007, 131, 1817-1820.

74. Fogo, A.; Superdock, K.R.; Atkinson, J.B. Severe arteriosclerosis in the kidney of a cocaine addict. Am. J. Kidney Dis. 1992, 20, 513-515. [CrossRef]

75. Su, J.; Li, J.; Li, W.; Altura, B.; Altura, B. Cocaine induces apoptosis in primary cultured rat aortic vascular smooth muscle cells: Possible relationship to aortic dissection, atherosclerosis, and hypertension. Int. J. Toxicol. 2004, 23, 233-237. [CrossRef]

76. Dabbouseh, N.M.; Ardelt, A. Cocaine mediated apoptosis of vascular cells as a mechanism for carotid artery dissection leading to ischemic stroke. Med. Hypotheses 2011, 77, 201-203. [CrossRef]

77. Ramondo, A.B.; Mistrorigo, F.; Angelini, A. Intimal hyperplasia and cystic medial necrosis as substrate of acute coronary syndrome in a cocaine abuser: An in vivo/ex vivo pathological correlation. Heart 2009, 95, 82. [CrossRef]

78. Steinhauer, J.R.; Caulfield, J.B. Spontaneous coronary artery dissection associated with cocaine use: A case report and brief review. Cardiovasc. Pathol. 2001, 10, 141-145. [CrossRef]

79. Kamineni, R.; Sadhu, A.; Alpert, J.S. Spontaneous coronary artery dissection: Report of two cases and a 50-year review of the literature. Cardiol. Rev. 2002, 10, 279-284. [CrossRef]

80. Meghani, M.; Siddique, M.N.; Bhat, T.; Samarneh, M.; Elsayegh, S. Internal carotid artery redundancy and dissection in a young cocaine abuser. Vascular 2013, 21, 243-245. [CrossRef]

81. Kozor, R.; Grieve, S.M.; Buchholz, S.; Kaye, S.; Darke, S.; Bhindi, R.; Figtree, G.A. Regular cocaine use is associated with increased systolic blood pressure, aortic stiffness and left ventricular mass in young otherwise healthy individuals. PLoS ONE 2014, 9, e89710. [CrossRef]

82. Kariyanna, P.T.; Jayarangaiah, A.; Al-Sadawi, M.; Ahmed, R.; Green, J.; Dubson, I.; McFarlane, S.I. A rare case of second degree Mobitz type II AV block associated with cocaine use. Am. J. Med. Case Rep. 2018, 6, 146-148. [CrossRef] [PubMed]

83. Satran, A.; Bart, B.A.; Henry, C.R.; Murad, M.B.; Talukdar, S.; Satran, D.; Henry, T.D. Increased prevalence of coronary artery aneurysms among cocaine users. Circulation 2005, 111, 2424-2429. [CrossRef] [PubMed]

84. Gupta, N.; Washam, J.B.; Mountantonakis, S.E.; Li, S.; Roe, M.T.; de Lemos, J.A.; Arora, R. Characteristics, management, and outcomes of cocaine-positive patients with acute coronary syndrome (from the National Cardiovascular Data Registry). Am. J. Cardiol. 2014, 113, 749-756. [CrossRef]

85. Salihu, H.M.; Salemi, J.L.; Aggarwal, A.; Steele, B.F.; Pepper, R.C.; Mogos, M.F.; Aliyu, M.H. Opioid drug use and acute cardiac events among pregnant women in the United States. Am. J. Med. 2018, 131, 64-71. [CrossRef] 
86. Aslibekyan, S.; Levitan, E.B.; Mittleman, M.A. Prevalent cocaine use and myocardial infarction. Am. J. Cardiol. 2008, 102, 966-969. [CrossRef]

87. Gunja, A.; Stanislawski, M.A.; Baron, A.E.; Maddox, T.M.; Bradley, S.M.; Vidovich, M.I. The implications of cocaine use and associated behaviors on adverse cardiovascular outcomes among veterans: Insights from the VA Clinical Assessment, Reporting, and Tracking (CART) Program. Clin. Cardiol. 2018, 41, 809-816. [CrossRef]

88. Arora, S.; Dodani, S.; Kaeley, G.S.; Kraemer, D.F.; Aldridge, P.; Pomm, R. Cocaine use and subclinical coronary artery disease in Caucasians. J. Clin. Exp. Cardiol. 2015, 6, 1-6.

89. Bamberg, F.; Schlett, C.L.; Truong, Q.A.; Rogers, I.S.; Koenig, W.; Nagurney, J.T.; Seneviratne, S.; Lehman, S.J.; Cury, R.C.; Abbara, S.; et al. Presence and extent of coronary artery disease by cardiac computed tomography and risk for acute coronary syndrome in cocaine users among patients with chest pain. Am. J. Cardiol. 2009, 103, 620-625. [CrossRef]

90. Chang, A.M.; Walsh, K.M.; Shofer, F.S.; McCusker, C.M.; Litt, H.I.; Hollander, J.E. Relationship between cocaine use and coronary artery disease in patients with symptoms consistent with an acute coronary syndrome. Acad. Emerg. Med. 2011, 18,1-9. [CrossRef]

91. Lai, H.; Moore, R.; Celentano, D.D.; Gerstenblith, G.; Treisman, G.; Keruly, J.C.; Kickler, T.; Li, J.; Chen, S.; Lai, S.; et al. HIV infection itself may not be associated with subclinical coronary artery disease among African Americans without cardiovascular symptoms. J. Am. Heart Assoc. 2016, 5, e002529. [CrossRef]

92. Lucas, G.M.; Atta, M.G.; Fine, D.M.; McFall, A.M.; Estrella, M.M.; Zook, K.; Stein, J.H. HIV, cocaine use, and hepatitis $C$ virus: A triad of nontraditional risk factors for subclinical cardiovascular disease. Arterioscler. Thromb. Vasc. Biol. 2016, 36, 2100-2107. [CrossRef]

93. DeFilippis, E.M.; Singh, A.; Divakaran, S.; Gupta, A.; Collins, B.L.; Biery, D.; Qamar, A.; Fatima, A.; Ramsis, M.; Pipilas, D.; et al. Cocaine and marijuana use among young adults with myocardial infarction. J. Am. Coll. Cardiol. 2018, 71, 2540-2551. [CrossRef]

94. Morentin, B.; Ballesteros, J.; Callado, L.F.; Meana, J.J. Recent cocaine use is a significant risk factor for sudden cardiovascular death in 15-49-year-old subjects: A forensic case-control study. Addiction 2014, 109, 2071-2078. [CrossRef]

95. Qureshi, A.I.; Chaudhry, S.A.; Suri, M.F. Cocaine use and the likelihood of cardiovascular and all-cause mortality: Data from the third national health and nutrition examination survey mortality follow-up study. J. Vasc. Interv. Neurol. 2014, 7, 76-82. [CrossRef]

96. Hser, Y.I.; Kagihara, J.; Huang, D.; Evans, E.; Messina, N. Mortality among substance-using mothers in California: A 10-year prospective study. Addiction 2012, 107, 215-222. [CrossRef] [PubMed]

97. Atoui, M.; Fida, N.; Nayudu, S.K.; Glandt, M.; Chilimuri, S. Outcomes of patients with cocaine induced chest pain in an inner city hospital. Cardiol. Res. 2011, 2, 269-273. [CrossRef]

98. Hollander, J.E.; Hoffman, R.S. Cocaine-induced myocardial infarction: An analysis and review of the literature. J. Emerg. Med. 1992, 10, 169-177. [CrossRef]

99. Pletcher, M.J.; Kiefe, C.I.; Sidney, S.; Carr, J.J.; Lewis, C.E.; Hulley, S.B. Cocaine and coronary calcification in young adults: The Coronary Artery Risk Development in Young Adults (CARDIA) study. Am. Heart J. 2005, 150, 921-926. [CrossRef] [PubMed]

100. Lai, S.; Lai, H.; Meng, Q.; Tong, W.; Vlahov, D.; Celentano, D.; Strathdee, S.; Nelson, K.; Fishman, E.K.; Lima, J.A. Effect of cocaine use on coronary calcium among black adults in Baltimore, Maryland. Am. J. Cardiol. 2002, 90, 326-328. [CrossRef]

101. Lai, S.; Lima, J.A.; Lai, H.; Vlahov, D.; Celentano, D.; Tong, W.; Bartlett, J.G.; Margolick, J.; Fishman, E.K. Human immunodeficiency virus 1 infection, cocaine, and coronary calcification. Arch. Intern. Med. 2005, 165, 690-695. [CrossRef] [PubMed]

102. Lai, S.; Fishman, E.K.; Lai, H.; Moore, R.; Cofrancesco, J., Jr.; Pannu, H.; Tong, W.; Du, J.; Barlett, J. Long-term cocaine use and antiretroviral therapy are associated with silent coronary artery disease in African Americans with HIV infection who have no cardiovascular symptoms. Clin. Infect. Dis. 2008, 46, 600-610. [CrossRef] [PubMed]

103. Wang, G.J.; Volkow, N.D.; Logan, J.; Pappas, N.R.; Wong, C.T.; Zhu, W.; Netusil, N.; Fowler, J.S. Brain dopamine and obesity. Lancet 2001, 357, 354-357. [CrossRef]

104. Volkow, N.D.; Wang, G.J.; Baler, R.D. Reward, dopamine and the control of food intake: Implications for obesity. Trends Cogn. Sci. 2011, 15, 37-46. [CrossRef] [PubMed] 
105. Mahapatra, A. Overeating, obesity, and dopamine receptors. ACS Chem. Neurosci. 2010, 1, 346-347. [CrossRef]

106. Thanos, P.K.; Cho, J.; Kim, R.; Michaelides, M.; Primeaux, S.; Bray, G.; Wang, G.J.; Volkow, N.D. Bromocriptine increased operant responding for high fat food but decreased chow intake in both obesity-prone and resistant rats. Behav. Brain Res. 2011, 217, 165-170. [CrossRef] [PubMed]

107. Ramamoorthy, S.; Bauman, A.L.; Moore, K.R.; Han, H.; Yang-Feng, T.; Chang, A.S.; Ganapathy, V.; Blakely, R.D. Antidepressant- and cocaine-sensitive human serotonin transporter: Molecular cloning, expression, and chromosomal localization. Proc. Natl. Acad. Sci. USA 1993, 90, 2542-2546. [CrossRef]

108. Yadav, V.K.; Oury, F.; Suda, N.; Liu, Z.W.; Gao, X.B.; Confavreux, C.; Klemenhagen, K.C.; Tanaka, K.F.; Gingrich, J.A.; Guo, X.E.; et al. A serotonin-dependent mechanism explains the leptin regulation of bone mass, appetite, and energy expenditure. Cell 2009, 138, 976-989. [CrossRef]

109. Vicentic, A.; Jones, D.C. The CART (cocaine- and amphetamine-regulated transcript) system in appetite and drug addiction. J. Pharmacol. Exp. Ther. 2007, 320, 499-506. [CrossRef]

110. Rogge, G.; Jones, D.; Hubert, G.W.; Lin, Y.; Kuha, M.J. CART peptides: Regulators of body weight, reward and other functions. Nat. Rev. Neurosci. 2008, 9, 747-758. [CrossRef] [PubMed]

111. Wortley, K.E.; Chang, G.Q.; Davydova, Z.; Fried, S.K.; Leibowitz, S.F. Cocaine- and amphetamine-regulated transcript in the arcuate nucleus stimulates lipid metabolism to control body fat accrual on a high-fat diet. Regul. Pept. 2004, 117, 89-99. [CrossRef] [PubMed]

112. Hunter, R.G.; Philpot, K.; Vicentic, A.; Dominguez, G.; Hubert, G.W.; Kuhar, M.J. CART in feeding and obesity. Trends Endocrinol. Metab. 2004, 15, 454-459. [CrossRef]

113. Balopole, D.C.; Hansult, C.D.; Dorph, D. Effect of cocaine on food intake in rats. Psychopharmacology 1979, 64, 121-122. [CrossRef] [PubMed]

114. Wolgin, D.L.; Hertz, J.M. Effects of acute and chronic cocaine on milk intake, body weight, and activity in bottle- and cannula-fed rats. Behav. Pharmacol. 1995, 6, 746-753. [CrossRef]

115. Church, M.W.; Morbach, C.A.; Subramanian, M.G. Comparative effects of prenatal cocaine, alcohol, and undernutrition on maternal/fetal toxicity and fetal body composition in the Sprague-Dawley rat with observations on strain-dependent differences. Neurotoxicol. Teratol. 1995, 17, 559-567. [CrossRef]

116. Castro, F.G.; Newcomb, M.D.; Cadish, K. Lifestyle differences between young adult cocaine users and their nonuser peers. J. Drug Educ. 1987, 17, 89-111. [CrossRef]

117. Ersche, K.D.; Stochl, J.; Woodward, J.M.; Fletcher, P.C. The skinny on cocaine: Insights into eating behavior and body weight in cocaine-dependent men. Appetite 2013, 71, 75-80. [CrossRef]

118. Quach, L.A.; Wanke, C.A.; Schmid, C.H.; Gorbach, S.L.; Mwamburi, D.M.; Mayer, K.H.; Spiegelman, D.; Tang, A.M. Drug use and other risk factors related to lower body mass index among HIV-infected individuals. Drug Alcohol Depend. 2008, 95, 30-36. [CrossRef]

119. Escobar, M.; Scherer, J.N.; Soares, C.M.; Guimaraes, L.S.P.; Hagen, M.E.; von Diemen, L.; Pechansky, F. Active Brazilian crack cocaine users: Nutritional, anthropometric, and drug use profiles. Braz. J. Psychiatry 2018, 40, 354-360. [CrossRef]

120. Muniz, A.E.; Evans, T. Acute gastrointestinal manifestations associated with use of crack. Am. J. Emerg. Med. 2001, 19, 61-63. [CrossRef]

121. Billing, L.; Ersche, K.D. Cocaine's appetite for fat and the consequences on body weight. Am. J. Drug Alcohol Abuse 2015, 41, 115-118. [CrossRef]

122. Ludwig, D.S.; Pereira, M.A.; Kroenke, C.H.; Hilner, J.E.; Van Horn, L.; Slattery, M.L.; Jacobs, D.R., Jr. Dietary fiber, weight gain, and cardiovascular disease risk factors in young adults. JAMA 1999, 282, 1539-1546. [CrossRef]

123. Rangel, C.; Shu, R.G.; Lazar, L.D.; Vittinghoff, E.; Hsue, P.Y.; Marcus, G.M. Beta-blockers for chest pain associated with recent cocaine use. Arch. Intern. Med. 2010, 170, 874-879. [CrossRef] 
124. Lopez, P.D.; Akinlonu, A.; Mene-Afejuku, T.O.; Dumancas, C.; Saeed, M.; Cativo, E.H.; Visco, F.; Mushiyev, S.; Pekler, G. Clinical outcomes of B-blocker therapy in cocaine-associated heart failure. Int. J. Cardiol. 2018. [CrossRef]

125. Dattilo, P.B.; Hailpern, S.M.; Fearon, K.; Sohal, D.; Nordin, C. Beta-blockers are associated with reduced risk of myocardial infarction after cocaine use. Ann. Emerg. Med. 2008, 51, 117-125. [CrossRef] 